\title{
Taking care of a real self - description of the psychotherapeutic process of a patient with narcissistic personality disorders in the field of dance/ movement psychotherapy
}

\begin{abstract}
Zaopiekować się prawdziwym JA - opis procesu psychoterapeutycznego pacjentki z zaburzeniami osobowości typu narcystycznego w nurcie psychoterapii tańcem i ruchem
\end{abstract}

Ewelina DrzałABCDEF https://orcid.org/0000-0003-1247-1558,

I Department of Psychiatry, Psychotherapy and Early Intervention, Medical Univercity of Lublin, Poland

\begin{abstract}
Introduction: Dance/movement psychotherapy (DMT) is a psychotherapeutic trend that belongs to the approaches that involve working with the body. Thinking about a wider perspective, DMT belongs to the group of action-oriented psychotherapies. It assumes that the person, while moving, can show his/her emotional states. Additionally, it can lead to development and personal integration. The goal is to deepen awareness. Psychotherapy with dance and movement is practiced among psychotic patients, patients suffering from neurotic or personality disorders, and as a method of personal development. The aim of the work is to describe the psychotherapeutic process of an individual client in the field of dance/movement psychotherapy as a method in which dance leads to development and personal integration.

Material and method: Working with a client, Beata, took place in a strictly defined setting. Meetings took place once a week in the same office during 55 minutes. They were of an individual nature. First, Beata was diagnosed according to the DSM-5 [1] and ICD-10 [2] classification, which was supplemented with the PDM-2 diagnosis [3]. During the therapeutic work, the phenomena of transference and countertransference were taken into account, the patient's behavior was interpreted according to John Bowlby's attachment theory and mentalization. During practicing DMT it is important to take care of Authentic Movement method, observation of movement using the Laban Bartenieff Movement System (LBMS) method and the Kastenberg Movement Profile (KMP).

Results: The changes that DMT psychotherapy started to bring were observed both in the client's movement and in the verbal layer. The client has acquired the ability to observe her feelings and needs. This influenced her perception of announcement heard from different people and the decisions she made. The DMT therapy with Beata is not over yet, which makes it possible to take a deeper look at topics related to therapeutic goals.

Conclusions: Dance/movement psychotherapy has proved to be an effective method of working with patients with personality disorders psychopathology of the narcissistic type. This method makes it possible to build a sense of the patient's boundaries and needs, and to strengthen self-esteem. Sessions seem to be very helpful in integrating inner life, feelings and experience. In addition, it helps in dealing with the internal tension of patients and gives the opportunity to expand ranges of movement. In the verbal part, it is possible to discuss the problems that the client carries within himself, which cause him fear, anxiety and other unpleasant emotions.
\end{abstract}

Keywords: DMT, psychotherapy, personality disorders, DSM-5, LBM

\section{Streszczenie}

Wprowadzenie: Psychoterapia tańcem i ruchem (DMT) jest nurtem psychoterapeutycznym, należącym do podejść obejmujących pracę z ciałem. Uwzględniając szerszą perspektywę, DMT zalicza się do grupy psychoterapii zorientowanych na działanie. Zakłada, że osoba poruszając się może ukazywać swoje stany emocjonalne. Dodatkowo ruch może prowadzić do rozwoju i osobistej integracji. Celem jest pogłębianie świadomości oraz wglądu. Psychoterapię tańcem i ruchem praktykuje się wśród pacjentów psychotycznych, cierpiących z powodu zaburzeń nerwicowych czy osobowości oraz jako metodę rozwoju osobistego. Celem pracy jest opis procesu psychoterapeutycznego u klientki indywidualnej prowadzony w nurcie psychoterapii 
tańcem i ruchem czyli metody, w której taniec ma prowadzić do rozwoju i osobistej integracji.

Materiał i metoda: Praca z klientką, Panią Beatą, odbywała się w ściśle określonym settingu. Spotkania miały miejsce raz w tygodniu, w tym samym gabinecie i trwały 55 min. Miały one charakter indywidualny. W pierwszej kolejności Pani Beacie postawiono rozpoznanie wg klasyfikacji DSM-5 [1] oraz ICD-10 [2], którą uzupełniono diagnostyką wg PDM-2 [3]. Podczas pracy terapeutycznej uwzględniano zjawisko przeniesienia oraz przeciwprzeniesienia, interpretowano zachowania pacjentki wg teorii przywiązania Johna Bowlby'ego oraz mentalizacji. Praktykując DMT czerpano z metody Ruchu Autentycznego, obserwacji ruchu metodą Laban Bartenieff Movement System (LBMS) oraz Profilu Ruchowego wg Kastenberg (KMP).

Wyniki: Zmiany, które zaczęła przynosić psychoterapia DMT zaobserwowano zarówno w ruchu Klientki jak i warstwie werbalnej. Klientka nabyła umiejętności przyglądania się swoim odczuciom i potrzebom. Wpłynęło to na jej postrzeganie komunikatów słyszanych od otoczenia oraz podejmowane decyzje. Terapia DMT z Panią Beatą jeszcze się nie zakończyła, co daje możliwość głębszemu przyjrzeniu się tematom związanym z celami terapeutycznymi.

Wnioski: Psychoterapia Tańcem i Ruchem okazała się skuteczną metodą pracy z pacjentami z psychopatologią zaburzeń osobowości typu narcystycznego. Metoda ta daje możliwość budowania poczucia granic i potrzeb pacjenta oraz wzmacnianie poczucia własnej wartości. Sesje wydają się być bardzo pomocne w integrowaniu życia wewnętrznego oraz przeżywanych uczuć. Dodatkowo pomaga w radzeniu sobie z napięciem wewnętrznym Pacjentów oraz daje możliwość poszerzenia swoich zakresów ruchowych. W części werbalnej możliwe jest omówienie problemów, które nosi w sobie Klient, a które powodują w nim lęk, niepokój i inne nieprzyjemne w odczuciu emocje.

Słowa kluczowe: DMT, psychoterapia, zaburzenia osobowości, DSM-5, LBM

\section{Introduction}

For centuries, dance has accompanied human, being the first known form of art and one of the main components of culture. It has become an indispensable part of human life as a tool for building collective identity and a language of non-verbal communication. Used in rituals of passage or integration, it served to overcome the fear of change, death, the unknown. Currently, it is most often associated with play and art [4].

Dance and movement psychotherapy emerged from contemporary dance, which emerged as a technique in the first half of the 20th century [5]. At that time, dance as an art was used not only as a form showing a fairytale world, unreal or detached from reality, but also as an expression of spiritual life, a way of expressing oneself, one's conflicts, frustrations and a sense of alienation. Soon after, the precursors started using movement for therapeutic purposes [6]. The idea of dance and movement psychotherapy was initiated in the United States by Marian Chace, and in Europe by Mary Whitehouse.

In the 20th century, two trends of dance therapy emerged. One is therapeutic dance, otherwise known as choreotherapy, the other is dance and movement psychotherapy (DMT, DMP). Both trends differ mainly in the type and importance of the therapeutic relationship, which results in the depth of change that the client can achieve [6].

Psychotherapy with dance and movement is a psychotherapeutic trend which assumes that a person by moving in an expressive way can show his/ her emotional states. It is a method where movement leads to development and personal integration. The psychotherapist creates conditions in which the client can express his/her emotions in a safe way and the feelings are accepted. DMT draws from many areas of knowledge, including in psychology, movement analysis, improvisation, assumptions of modern dance, but also in art and philosophy [6].

\section{Material and method}

From November 2020 to November 2021, DMT psychotherapy was leaded with a client, Beata. Psychotherapy sessions were held once a week and lasted 55 minutes. In the past, the client attended verbal psychotherapy. The name and details of the patient have been changed for the purposes of this work.

Before beginning of the work with Beata, the diagnosis was made according to the DSM-5 [1] and ICD-10 [2] classification, which was supplemented with the diagnosis according to the PDM-2 Psychodynamic Diagnosis Manual [3]. The patient was diagnosed with narcissistic personality disorders.

During the session, the phenomena of transference and countertransference were observed, body sensations and emotions were observed. The patient's behavior was interpreted according to John Bowlby's attachment theory, which states that the styles of entering into relationships with other people are shaped during childhood through the attachment relationship with parents. The sense of security in the relationship with caregivers influences the style of coping with difficult situations or stress occurring during life. It also influences the intensity of their experience [7]. Using this theory, a more conscious selection of strategies for building a therapeutic 
Table 1. Comparison of dance and movement psychotherapy with choreotherapy (source: [6])

\begin{tabular}{|c|c|c|}
\hline Area & $\begin{array}{c}\text { Dance/movement } \\
\text { psychotherapy }\end{array}$ & Choreotherapy \\
\hline Education of the lecturer & $\begin{array}{l}\text { Minimum four years of training } \\
\text { covering extensive knowledge } \\
\text { in the field of psychology and } \\
\text { psychotherapy }\end{array}$ & $\begin{array}{l}\text { Two-year training or a series of } \\
\text { workshops covers elements of } \\
\text { psychological theories }\end{array}$ \\
\hline The teacher's own therapy & Required & Recommended \\
\hline Supervision of therapeutic work & Required & Required during training \\
\hline The main healing factor & Therapeutic relationship & Dance \\
\hline Objectives & $\begin{array}{l}\text { Determined by the specific needs } \\
\text { of patients }\end{array}$ & $\begin{array}{c}\text { Generally therapeutic, sometimes } \\
\text { educational or artistic }\end{array}$ \\
\hline Process-based work & Yes & No \\
\hline $\begin{array}{c}\text { Choreographies proposed by the } \\
\text { teacher }\end{array}$ & $\begin{array}{l}\text { Possible if they serve current } \\
\text { therapeutic goals }\end{array}$ & Yes \\
\hline Using of improvisation & Yes & Possible \\
\hline $\begin{array}{l}\text { Work with inner imagination and } \\
\text { symbolism }\end{array}$ & Yes & Possible \\
\hline Use of rhythm & Yes & Yes \\
\hline Use of music & Possible & Yes \\
\hline Number of people in the group & Up to 10 & Up to 30 \\
\hline $\begin{array}{l}\text { The touch between the therapist } \\
\text { and the client }\end{array}$ & $\begin{array}{l}\text { Rarely used, in any case negotiated } \\
\text { in advance with the patient }\end{array}$ & $\begin{array}{l}\text { Usually as part of common } \\
\text { interactions }\end{array}$ \\
\hline Verbal discussing experiences & Yes & Possible \\
\hline $\begin{array}{l}\text { The use of motion observation } \\
\text { for diagnostic and therapeutic } \\
\text { purposes }\end{array}$ & Yes & Rarely seen \\
\hline
\end{tabular}

relationship was made. The theory of mentalization ability was important in building a concept about the patient and selecting interventions. Psychologists have been using this concept since the 1970s [8]. This process is understood as "a form of pre-conscious, imaginative mental activity, consisting in perceiving and interpreting human behavior in terms of intentional mental states (e.g. needs, desires, feelings, beliefs, goals, intentions, reasons)" [9]. What is important here is the mental process, the ability to create representations of mental states, and the differentiation between internal and external reality [10]. In building a relationship with Ms Beata, the therapist used empathic tuning to the client, explored the feelings aroused by the patient [11], [12] and used the client's delicate exposure to her emotions related to dependence [13], [14]. In this matter, the humanistic approach was important, it focused on active listening, showing caring, sharing one's own feelings, and in situations when it helps the client, sharing current emotional experiences with him/her [15].

In practicing DMT with Beata, the words of Janet Adler were inspiring: "When I witness your movement, I cannot know anything about your experience. I can only know my experience in your presence. I am committed to following my experiences as best I can. My intention, my task is to notice everything that arises in me when I am a witness" [16]. Supervisions had a great influence on building the motor relationship with the patient. The therapist supervising the process, in her work, draws on the Mary Whitehouse Authentic Movement method, looking at the client's movement in a supportive, nonjudgmental way [17]. During the observation of the client's movement, elements of the Laban Bartenieff Movement System (LBMS) and the Kastenberg Movement Profile (KMP) were used.

\section{Initial interview}

Beata is 29 year old, she is married, childless, she has higher education and lives with her husband. She comes from a small town in central-eastern Poland. Currently, she has been living in a large city for 10 years. The patient is from the 1st pregnancy, 1st delivery, born at term, she obtained 10 points on the Apgar scale. She did not go to nursery or kindergarten. In the first years of her life, she was looked after by her grandmothers: "I spent my childhood either with one grandmother or the other grandmother." She went to kindergarten at the age 
of 6 , at the age of 7 to primary school. After completing the 6th grade, she attended a junior high school. At that time, she was very involved in the life of the school, she took up important student functions, such as the head of the class and school, she sold in the school shop, participated in subject contests and school academies: "From kindergarten to the end of junior high school, I was the school elite". She did not repeat her classes, did not skip school, her behavior was exemplary or very good, she studied very well. Then she started high school. She went to a larger city to study in high school and lived in a school dormitory. She talks about this period in the following words: "In high school, I turned from a Friday schoolgirl to three and four", "I was a gray mouse who did not lean out", "In high school I had no social life". At the age of 19 , she began her studies, which she graduated after 6 years. Since then, she has been living in a big city. After graduation, she worked in a corporation. She says she did not like the job: "I've done my best to get me fired." For over a year she has been working in a smaller company as an office assistant and recruiting new employees. The client describes herself as a believer and practitioner of the Roman Catholic faith.

The patient's mother is middle-aged, she has higher education, and is still professionally active. When Beata was about 4 years old, her mother got another pregnancy, which she had a miscarriage. Two years later, the patient's brother was born. The patient has a difficult relationship with her mother: "My mother was always the beating and screaming one", "My mother was too much in my life", "My mother always compared me to others". The client recalls that her opinion and her brother's opinion did not matter to mother who, in the sense of the patient, put relations with other people first, not with children: "I was always surprised that she was so great for others, and for us she could be a monster. The patient's father is over 60 , has secondary education, and has been working abroad for many years. The patient has a good relationship with her father, although she only sees him on Christmas occasions. She says that she has always had better conversations with her father than with her mother, and that they have a stronger relationship: "All my life it seemed to me that I was daddy's little girl". The patient has a 6 years younger brother who is the driver: "This is not a strong, strong contact". Recently, the brother has tried to establish a closer relationship with the patient, but she is reluctant to talk to him, she is distrustful of him.

The patient's husband is her age, he has higher education, and works in a small company. From the patient's account: "He treats work as work, he does not get involved in it". She began a partnership relationship with her husband, who grew up in a small town, near the patient's home village, during her studies. Initially, their relationship was very good. The patient appreciated her husband for resourcefulness and broad interests. Approximately six months after the wedding, according to the patient's report, her husband changed his habits, started to follow diets, became interested in bioenergy therapy, started working on his relationship with God, he takes less account of his wife's opinion than before the wedding. In the following months, despite the selfpsychotherapy started by the patient, conflicts and quarrels grew in the marriage, culminating in her husband's leaving the house. After a few days, the young people reconciled, but this situation conflicted the families of origin of the spouses. The couple went to one marriage therapy meeting, where the husband was recommended to start his own psychotherapy. He did not follow the recommendation. As Mrs. Beata says: "He started going to church every day and going to confession more often". In recent months, he has been relegated at work, according to the client, because he was not involved enough in the life of the company. Certain behavior of the husband causes great fear, internal anxiety and irritation in the client.

Beata has not been treated psychiatrically or addicted to drugs so far. Approximately 3 months before starting DMT psychotherapy, she completed psychodynamic psychotherapy, in which she managed to achieve some of the goals she set for herself. Finding out about relationships with loved ones was still a big problem. With somatic health problems, the patient is diagnosed with insulin resistance, for which she follows a diet, and difficulties in getting pregnant, for which she is intensively diagnosed and treated. The client likes to cook and bake, she prepares meals for herself and her husband. She is following a low-carbohydrate and dairy-free diet. She rests in an active way, going for walks, climbing in the mountains. It is difficult for her to remain idle. During weekends, she and her husband travel to their parents or one of their friends or family comes to see them.

The reasons of applying for psychotherapy were given by the problem of aggression directed at her husband: "I terrorized my husband in frenzy", "I told him that I would jump out of the window", "I almost broke his nose once". Mental deterioration in the form of irritability, psychomotor restlessness, verbal and periodically physical aggression towards her husband has been observed to a great extent for about 2 years, but the client says that since the teenage years she has sometimes been irritable in contacts with other people. Recently, thoughts of resignation have appeared, but she denies the occurrence of suicidal thoughts. In the last few weeks, before starting DMT psychotherapy, the situation in the patient's marriage was relatively stabilized. The client started to withdraw from conflicts, get more involved in work, and did not fulfill her needs at home. The difficulties that the patient mentions as accompanying her from the 
early teenage years include problems in understanding her emotions and verbalizing her needs. Additionally, Beata has a strong need to control her life and surroundings. In many situations, she strives for perfection, and if she does not achieve it, she becomes angry with herself: "for being inept". She has trouble resting, during which she feels tension and remorse: "I'm so lazy". The client has difficulty enjoying her successes and a tendency to hide them from her relatives (e.g. promotion at work). She sees the cause of the problems she is struggling with in her relationship with her mother, who, in Beata's mind, did not give her sufficient closeness, warmth and attention.

\section{Diagnostics}

To diagnose Beata, the classification of mental and behavioral disorders in ICD-10 was used [2]. Due to the fact that the client is accompanied from an early age of adolescence with behaviors characteristic of her, not resulting directly from the disease, damage or other trauma to the brain or other mental disorder, she was diagnosed with a personality disorder [2]. In the case of Beata, behavioral changes cover several areas of functioning and are associated with personal problems and social disruptions [2].

The American Psychiatric Association DSM-5 Diagnostic Criteria for Mental Disorders was used to broaden the diagnosis [1]. Due to the fact that the client shows a constant pattern of behavior and experiencing emotions, which has occurred since the teenage years, and which causes impairment in social functioning and other important areas of life, it is possible to diagnose the patient with a personality disorder. Additionally, Beata's behavior in terms of expressing emotions, functioning in interpersonal relationships and controlling impulses is devoid of flexibility and differs from what is expected in her cultural circle. Her behaviors are not caused by the effects of psychoactive substances, because the client does not use nicotine, drugs or designer drugs, and drinks alcohol sporadically. Additionally, there is no reason to believe that her condition results from other general medical disorders.

Recognition of Beata's personality type was not obvious. Initially, she presented herself as a person with the personality traits of the C-cluster according to DSM5 (avoidant, dependent, obsessive-compulsive), with an indication of obsessive-compulsive personality. However, after getting to know the client more closely, it was noticed that most of her difficulties in interacting with others resulted from a marked weakening of her self-esteem. In her statements, there was often a conviction that she must be perfect to accept herself and be liked by others. In contact with Beata, the psychotherapist often felt her shame and a sense of humiliation. During the sessions, she sometimes mentioned feelings of jealousy. Then the researchers' attention turned to the B cluster according to DSM-5, personality disorders associated with a deficit of empathy (antisocial, borderline, histrionic, narcissistic) [18]. The diagnosis was narrowed down thanks to observations related to Beata's sensitivity to herself and her susceptibility to being "hurt", as a result of which the client tormented herself with criticism of her own person and experienced humiliation, worthlessness and emptiness. Mrs. Beata meets the criteria of a narcissistic personality disorder according to DSM-5 in terms of: absorption with ideas about success, perfection, ideal love, feeling of being someone special, need to be admired, limited compassion, feeling jealous towards others, occasional arrogant behavior [1].

Additionally, for diagnostic purposes, the patient's functioning profile was performed according to PDM-2 [3]:

Assessment of personality syndromes on the P axis:

Mrs. Beata is quite well adapted to family conditions, work and interests. Nevertheless, in stressful situations, she behaves in a destructive way for herself and her husband. Characteristic for her is the inner feeling of emptiness and senselessness of her actions. She needs external confirmation of her value, and if she does not receive it, he feels despondent, ashamed and jealous. Beata exhibits narcissistic personality traits of the "thinskinned" [19], "sensitive" [20], [21] and "fragile" type [22]. Assessment of the capacity on the M-axis:

- In the indicator of the ability to regulate, attention and learning [23], [24], Mrs. Beata is anchored at the level of 4 points, which means that she is focused, well organized, and can express her thoughts and emotions. Memory, attention and executive functions are well integrated, but under stress they deteriorate and limit them.

- The client seems to experience and communicate her emotional states in a limited way and has difficulty experiencing, for example, anger or sadness. She often reacts to the emotional signals of others in a dysfunctional, asynchronous, disproportionate manner, which gives her a score of 3 on the indicator of the ability to experience, communicate and understand emotions [25], [26].

- Looking at Mrs. Beata from the perspective of her ability to infer about her emotional states and mental states of other people [27], she was assessed at 3 points. The client is able to think and understand her own needs, desires and feelings, and to conclude about the internal experiences of other people. However, in the event of a conflict or intense emotions, there is a noticeable reduction in the ability to mentalize.

- In the sphere of identity [28], [29], Beata reaches level 3 by being able, with certain limitations and oversimplification, to differentiate and integrate 
experiences. In the case of the client, under the influence of strong emotions, the internal experience polarizes.

- The ability to build relationships and intimacy [30], [31] can be assessed at level 3. Beata is capable of intimacy, care and empathy, but when she begins to feel strong emotions, such as fear, anger or shame, she withdraws from the emotions, demands attention, love and care. The deficit in the ability to receive support from others is quite clear.

- The functioning of the patient shows that strong emotions easily weaken her self-esteem and selfconfidence, which means that her ability to regulate her self-esteem and high-quality internal experience [32], [33] reaches level 3.

- Mrs. Beata, when functioning in situations burdened with affect, has difficulties in controlling and regulating impulses. It also tends to be over-controlling, indicating that her ability to modulate impulses and express needs [34] is at level 3 .

- Beata's ability to function defensively [35] is at the highest, fifth level, because adaptive defense mechanisms predominate.

- The client shows disturbances in the ability to adapt, mental resilience and endurance [36], which means that these abilities are situated on the 3rd level.

- Mrs. Beata seems to be motivated to self-observation and able to reflect. However, under severe stress, her psychological attitude worsens and her subjective ability to experience others and herself changes significantly. This means that her self-observation ability [37] reaches level 3 according to PDM-2.

- Beata's ability to construct and use internal standards and ideals [38] ranks on level 3, as it is quite rigid and inflexible in this area of intrapsychic possibilities. Additionally, she shows a shaky self-esteem, and the guilt she feels takes on the task of a self-critic.

- The client shows a certain sense of purpose and meaning. However, her doubts often arise. Then she says: "What I am doing is pointless, it is not important". Additionally, Mrs. Beata accepts other points of view in spheres that do not contradict her basic ideals. It is level 3 in the scale of assessing the ability to give meaning and purpose [38].

By counting the points of functioning on the $\mathrm{M}$ axis according to PDM-2 (Table 1), the overall result achieved by Beata was 39, which gives us the M04 - Borderline range [3], i.e. moderate impairment in mental functioning (Table 2).

Table 2. Capacity assessment on the M axis (source: [3])

\begin{tabular}{|c|c|c|c|c|c|}
\hline Capability of the M-Axis & \multicolumn{3}{|c|}{ Rating scale } \\
\hline The ability to regulate, pay attention and learn & 5 & 4 & 3 & 2 & 1 \\
\hline The ability to experience, communicate and understand emotions & 5 & 4 & 3 & 2 & 1 \\
\hline Ability to mentalization and reflective functioning & 5 & 4 & 3 & 2 & 1 \\
\hline The ability to differentiate and integrate (identity) & 5 & 4 & 3 & 2 & 1 \\
\hline Ability to build relationships and intimacy & 5 & 4 & 3 & 2 & 1 \\
\hline The ability to regulate self-esteem and high-quality inner experience & 5 & 4 & 3 & 2 & 1 \\
\hline Ability to control and regulate impulses & 5 & 4 & 3 & 2 & 1 \\
\hline The ability to function defensively & 5 & 4 & 3 & 2 & 1 \\
\hline Adaptability, mental resilience and endurance & 5 & 4 & 3 & 2 & 1 \\
\hline Self-observation (psychological attitude) & 5 & 4 & 3 & 2 & 1 \\
\hline The ability to construct and use internal standards and ideals & 5 & 4 & 3 & 2 & 1 \\
\hline The ability to make sense & 5 & 4 & 3 & 2 & 1 \\
\hline & 0 Overall result \\
\hline
\end{tabular}

Assessment of personality syndromes on the P axis:

During the session, Mrs. Beata devotes a lot of space to the topic of her fertility. She and her husband have been trying for a child for 2 years or less. The patient is currently undergoing intensive diagnosis in this direction. She observes the mucus daily. She performs a transvaginal ultrasound weekly to monitor the phase of her cycle. She is taking medications to help break the egg sacs. It is difficult for doctors to find the tangible reason why Beata is not pregnant. The client has a strong fear that she will never be able to have children. This pattern of symptoms indicates disorders with somatic and related symptoms, namely disorders with anxiety about health (S52) [39].

\section{First sessions:}

Meetings with the client started with 3 qualifying and diagnostic sessions, during which it was possible to observe that Beata is a neat, slim, quite pretty, young woman. She would come to the sessions adequately 
Table 3. M-axis capability level (source: [3])

\begin{tabular}{|c|c|c|}
\hline Level / range & Title & Description \\
\hline \multicolumn{3}{|l|}{ Healthy } \\
\hline M01; 54-60 & $\begin{array}{l}\text { Healthy / Optimal } \\
\text { Mental Functioning }\end{array}$ & $\begin{array}{l}\text { Optimal to very good functioning on all or most psychological } \\
\text { abilities, with slight predictable variations in flexibility and } \\
\text { adaptation in different contexts. }\end{array}$ \\
\hline \multicolumn{3}{|l|}{ Neurotic } \\
\hline M02; 47-53 & $\begin{array}{l}\text { M02; 47-53 } \\
\text { Good / proper mental } \\
\text { functioning with some } \\
\text { areas of difficulty }\end{array}$ & $\begin{array}{l}\text { Adequate level of mental functioning, with some specific } \\
\text { areas of difficulty (e.g. in terms of three or four abilities). } \\
\text { These difficulties may arise from conflicts or challenges } \\
\text { related to specific situations or life events. }\end{array}$ \\
\hline M03; 40-46 & Mild mental impairment & $\begin{array}{l}\text { Mild restraints and inflexibility in some areas of mental } \\
\text { functioning, indicating rigidity and impairment in areas such } \\
\text { as self-esteem regulation, impulse and affect regulation, } \\
\text { defensive functioning, and self-observation. }\end{array}$ \\
\hline \multicolumn{3}{|l|}{ Borderline } \\
\hline M04; 33-39 & $\begin{array}{l}\text { Moderate mental } \\
\text { impairment }\end{array}$ & $\begin{array}{l}\text { Moderate limitations and lack of flexibility in most or almost } \\
\text { all spheres of mental functioning, which affects the quality } \\
\text { and stability of relationships, the sense of identity and the } \\
\text { range of tolerated affects. Functioning begins to reflect } \\
\text { the markedly impaired adaptations that are described as } \\
\text { borderline in many psychodynamic works and that occur, } \\
\text { with increasing severity, on the next two levels. }\end{array}$ \\
\hline M05; 26-32 & $\begin{array}{l}\text { Severe impairment in } \\
\text { mental functioning }\end{array}$ & $\begin{array}{c}\text { Serious limitations and changes in almost all spheres of } \\
\text { mental functioning (e.g. tendencies to fragmentation and } \\
\text { difficulties in differentiating the self and the object), along } \\
\text { with a reduction in the experience of feelings and / or } \\
\text { thoughts in the most important spheres of life (i.e. love, work, } \\
\text { play). }\end{array}$ \\
\hline M06; 19-25 & $\begin{array}{l}\text { Significant defects in } \\
\text { basic mental functions }\end{array}$ & $\begin{array}{l}\text { Significant defects in most spheres of mental functioning, } \\
\text { along with problems in the organization and / or integration } \\
\text { - the differentiation of the self and the object. }\end{array}$ \\
\hline \multicolumn{3}{|l|}{ Psychotic } \\
\hline M07; 12-18 & $\begin{array}{l}\text { Serious / severe } \\
\text { defects in basic mental } \\
\text { functions }\end{array}$ & $\begin{array}{l}\text { Serious and severe defects in almost all spheres of } \\
\text { mental functioning, including impaired study of reality; } \\
\text { fragmentation and / or difficulties in differentiating the self } \\
\text { and the object; disorders of perception, integration, and } \\
\text { regulation of affect and thought, and defects in at least one } \\
\text { basic mental function (e.g. perception, movement, memory, } \\
\text { regulation, judgment). }\end{array}$ \\
\hline
\end{tabular}

dressed. Her clothes were always color-matched, ironed and neat. The timbre of her voice is high, girlish. During the session, she spoke a lot and quickly. The main topics she articulated were trying for a child, conflicts with her husband, and difficulty in setting limits by taking on responsibilities at work. The subject of the patient's mother came up frequently, especially in situations where she was beginning to blame herself for a certain situation. She also talked a lot about closeness and often feeling lack of attention from others. Frequent conflicts with her husband broke out mainly when Beata felt unnoticed, unheard of or ignored by him. While discussing these situations, the client's statements included flashbacks from the family home when she felt similar in her relationship with her mother. People prone to exaggerate violent behavior in relationships with others, feeling underestimated by people who are important to them, looking for closeness with another person, show an anxious-ambivalent style of attachment as the only possibility to achieve happiness [7]. Research on attachment and mentalization in people with diagnosed narcissistic and borderline personality disorders indicate insecure attachment styles [40], [41] that result in unsatisfactory, confusing, unpredictable relationships with relatives in early childhood [42], [43]. 
Beata's description of her mother would support this theory.

\section{Observation of the client's movement:}

Meetings with the client started with 3 qualifying and diagnostic sessions, during which it was possible to observe that $\mathrm{B}$

When Beata moved during the first sessions, she was dominated by the swaying rhythm, the up-down and right-left developmental pattern, light weight, compact flow, unidirectional, free time, taking the shape of a wall. She put her legs on the ground and quite often lifted her heels off the ground. Her hands and shoulders were tense, controlling, they practically did not move.

The rocking rhythm according to the characteristics of Kestenberg's developmental rhythms (Table 4) is characteristic of the first half of the 4th year of life [44]. From the level of the present, it can be suspected that Beata is very committed to trying to get pregnant, and due to the psychological topic of caring and parenting, this rhy thm may be very close to her. However, when exploring the history of the client and her family, it is noticed that the patient's mother miscarried her child when she was about 4 years old. It was such a trauma for the family that the client feels that she should not talk about it with her mother or father, and the patient's still living grandmother quickly ends discussions related to those experiences, because she does not want to raise this issue. It can be suspected that at that time the patient's mother was emotionally unavailable to her, which influenced the transfer of trauma from the parent's generation to the client's generation. It is mentioned in the literature that the trauma experienced by a child stops the occurrence of subsequent developmental rhythms [44].

Beata's movement is dominated by up-down and right-left development patterns (Table 5). According to LBMS, developmental patterns concern the body, feeling, senses and sensations [45]. The fact that the client lacks

Table 4. Developmental rhythms (source: own elaboration based on [44])

\begin{tabular}{|c|c|c|c|}
\hline Age & Phase & $\begin{array}{l}\text { Engalding rhythms } \\
\text { (first half age) }\end{array}$ & $\begin{array}{l}\text { Fighting rhythms } \\
\text { (second half age) }\end{array}$ \\
\hline 1 year of age & Oral & $\begin{array}{l}\text { Sucking } \\
\text { Psychological topics: } \\
\text { the need for comfort, } \\
\text { support, relief, } \\
\text { attachment }\end{array}$ & $\begin{array}{c}\text { Biting } \\
\text { Psychological topics: } \\
\text { separation, formation of } \\
\text { boundaries }\end{array}$ \\
\hline 2 year of age & Anal & $\begin{array}{c}\text { Twisting } \\
\text { Psychological topics: } \\
\text { creativity, willingness to } \\
\text { change }\end{array}$ & $\begin{array}{c}\text { Strain } \\
\text { Psychological topics: } \\
\text { autonomy, intentions, } \\
\text { self-determination }\end{array}$ \\
\hline 3 year of age & Urinary & $\begin{array}{c}\text { Running } \\
\text { Psychological topics: } \\
\text { no purpose }\end{array}$ & $\begin{array}{l}\text { Run-stop-go } \\
\text { Psychological topics: } \\
\text { impulse control }\end{array}$ \\
\hline 4 year of age & Intragenital & $\begin{array}{c}\text { Swaying } \\
\text { Psychological topics: } \\
\text { caring, parenting }\end{array}$ & $\begin{array}{c}\text { Surging } \\
\text { Psychological topics: }\end{array}$ \\
\hline 5 year of age & Extragenital & $\begin{array}{c}\text { Jumping } \\
\text { Psychological topics: } \\
\text { assertiveness, building } \\
\text { relationships }\end{array}$ & $\begin{array}{c}\text { Spurting } \\
\text { Psychological topics: } \\
\text { rivalry }\end{array}$ \\
\hline
\end{tabular}

Table 5. Development patterns (source: own elaboration based on information from LBMS and [50] lectures)

\begin{tabular}{|c|c|}
\hline Development patterns: & Psychological topics: \\
\hline Breath & About being \\
\hline Cor-distal & About going outside, collecting information \\
\hline Head-tail & About fun, pleasure, possibilities \\
\hline Up and down & About strength, power, agency \\
\hline Right-left & About the decision, the hesitation \\
\hline Alternating & About possibilities, integration and consistency \\
\hline
\end{tabular}


Table 6. Basic elements of dynamic Effort qualities [6]

\begin{tabular}{|c|c|c|}
\hline Qualities & $\begin{array}{c}\text { Association } \\
\text { Experience } \\
\text { evoked }\end{array}$ & Association Experience evoked \\
\hline $\begin{array}{c}\text { LIGHT } \\
\text { strong weight } \text { effort/ }\end{array}$ & Intentiont effort & $\begin{array}{c}\text { Weight refers to the feeling of the body itself, skin, bone, sense } \\
\text { of touch, experience of life. The element of burden is associated } \\
\text { with exerting an influence, a sense of being. }\end{array}$ \\
\hline $\begin{array}{c}\text { SPACE } \\
\text { indirect space effort/ } \\
\text { direct space effort }\end{array}$ & Attention & $\begin{array}{c}\text { Space refers to outward focus, perspective, engaging the mental } \\
\text { aspect of the personality. It also determines the direction of } \\
\text { movement. Where is the attention directed? On myself, on } \\
\text { others, on space, loose, taut. }\end{array}$ \\
\hline $\begin{array}{c}\text { sustained time effort/ } \\
\text { quick time effort }\end{array}$ & Decisions & $\begin{array}{c}\text { Time relates to impulses, decisions, phrases, and rhythms. It is } \\
\text { connected with intuition. The experience of choices and how } \\
\text { to transition between different qualities is associated with the } \\
\text { element of time. }\end{array}$ \\
\hline $\begin{array}{c}\text { FLOW } \\
\text { free flow effort/bound } \\
\text { flow effort }\end{array}$ & Development & $\begin{array}{c}\text { Flow of energy, breath or life force. Holding or expressing } \\
\text { feelings, experiencing emotions in the body. How does the flow } \\
\text { of energy and feelings open or close the relationship, how does it } \\
\text { give direction to the relationship? Flow is also the level of traffic } \\
\text { control. }\end{array}$ \\
\hline
\end{tabular}

an alternating pattern may indicate the lack of integration of her inner life and the lack of consistency in experienced feelings. In Dynamic Movement Qualities Beata presents light weight, free time and unidirectional, which gives an action drive called glide [46]. The glide is usually long-lasting, light, direct, it is usually accompanied by limited flow, it does not give in to space. Interpreting the individual qualities of movement and taking into account that weight indicates intention, flow indicates a sense of control, time about decisions made, and space about attention, we can infer about the emotions of the client [46] (Table 6). Its dense flow tells us about her need to control herself and the environment, which is additionally connected with tightened cheekbones and shoulders. The psychotherapist, accompanying Beata in motion and trying to reflect her dance in her body, had a feeling of being in control of herself, not letting any affect to herself. In the patient's space, it is one-way, which may indicate that it is easy to focus on the goal, which is confirmed by the interview collected with the patient about her work and organization. Light weight may indicate difficulty in giving intentions to your actions. This observation seems to be consistent with the not fully specified desire to be pregnant by Beata. The client has many ambivalent emotions towards having a child. On the one hand, she wants to get pregnant very much, and her actions are strongly focused on it, on the other hand, she is afraid of the obligations related to having a child and the difficulties resulting from it. In addition, the client mentioned that she sometimes heard comments at work about her inaccuracies and difficulties in organizing tasks. The patient presents her free time on the move, which in turn corresponds to the interview collected from the client, in which she confirms that she has difficulty making quick decisions, often reflects on the rightness of her choices, prefers to get to know the topic as best as possible to make a decision. In the context of Beata, the shape of the wall is interesting, which would indicate distrust and set rigid boundaries in relations with other people, but this shape should not necessarily be surprising in the face of the patient's difficulties, because it may show protection and not allowing intimacy in the relationship.

From the observation of the patient's movement, a hypothesis was drawn that she is an ambitious, wellorganized person who tries to control her surroundings on a daily basis. At the same time, she may have difficulty sharing responsibility, recognizing her own boundaries, and may have a tendency to assume the responsibilities of others.

\section{Results}

After the initial sessions, the goals of psychotherapy began to be clarified. Beata mentioned her need first: "I would like not to HAVE TO, but to WANT, for example, to clean up, cook for my husband, because I love him". She was asked what would happen if she no longer HAD TO, she would found that she DOESN'T WANT TO. She could not answer that question, but she agreed to modify and verbalize the first target, and then the others:

1. "Not to have to" - not to respond to internal compulsion right away, but to think about it.

2. "Knowing where my needs end and the needs of the world begin" - working on your own borders.

3. "Stop being afraid that I won't be able to do it" start working on building your self-esteem. 
4. Learning to let go of tasks, give them back, share responsibility.

While formulating the goals of psychotherapy, Beata did not include in them the will to work on the adequate expression of anger. It was an aspect that the client preferred not to notice in herself and not to touch on. From the point of view of psychotherapy, it seemed important to raise this topic when working on your own boundaries or recognizing your needs. It was seen as a possibility for Beata to be able to express her potential discomfort earlier and more consciously, and not to react with an attack when she feels that there is no other way to defend herself from the overwhelming amount of duties.

It soon turned out that the client was not ready to start working on the fourth therapeutic goal. She often said that if she let go of a task, she would feel guilty. In fact, she would lose proof of her uniqueness, and this feeling is very much needed by people with a personality disorder of the narcissistic type to feel important and worthwhile. Her difficulty in handing over responsibility to others became apparent during the experience as the client and the psychotherapist stretched using a piece of cloth. When it was suggested that the Patient, holding the material, should give up her weight and allow herself to lean out of the vertical, and the psychotherapist holding the other end would hold her, Beata was unable to do so. In addition, it gave a signal that the client does not fully trust the psychotherapist, does not believe that she could support her, not only physically. As far as the implementation of the fourth goal is concerned, it was noted that in order for it to become achievable, a satisfactory therapeutic relationship was needed. An accessible and empathetic psychotherapist could give the Patient a sense of security necessary for growth, stopped in self-development [47]. A way of working and being with the client, similar to that characteristic of the Authentic Movement, was used to build a favorable space for the creation of a therapeutic relationship. Looking at the client's movement in a supportive, non-judgmental way, naming what is happening in the relationship and in the psychotherapist, empathic tuning and reflecting helped build trust between Beata and the therapist [17].

The work with the client started with her sense of security. This was achieved thanks to, among other things, the experience with looking for a safe place in the office where we worked. The client traveled slowly around the room. For a long time she could not decide on one place, which was associated with her difficulty in making decisions. Finally she sat down on the sill of the only window in the room. After a while she got up and carried all the plants in the office to the windowsill. She also took her purse with her. When she sat down on the windowsill herself, she began to look out the window. While talking to the psychotherapist about her experiences, she did not take her eyes off what was happening outside the window. This behavior was associated with her great need to control. On the one hand, by allowing the plants to be rearranged in the office, Beata felt that she had an influence on the changes that would take place in the process, on the other hand, there was a concern that the patient would not tend to try to control the session. The fears were later confirmed. It was noticed that some of the verbal comments that Beata received from the psychotherapist were denied or ignored, only to bring them back in 2 or 3 sessions as her thoughts from the previous week. This indicated the client's difficulties in remaining in a dependency relationship.

A therapeutic relationship was built in motion. Often used to mirroring Beata's dance. At first, the client felt surprised, at times confused and did not know how to relate to it. She often asked if she was doing everything right, if she was doing things properly. In turn, in the psychotherapist's feelings there was inadequacy, a certain kind of blaming herself for the patient's potential discomfort, which was not verbalized by her: "I am afraid that I am too confronting, despite the fact that Beata says that she has nice feelings from the session ". These ambivalent feelings were probably related to the client and her uncertainty, perhaps frustration in the initial phase of building a relationship. With time, the decision to be empathetic and to be with the patient resulted in a change in her movement and feeling. Beata seemed to be more free in her movement, she talked about the feeling of being noticed, important.

Her psychotherapist being with Beata during the first sessions, had difficulty finding her sense of center in the body. In her notes, she wrote: "I feel my stomach rising to my throat. I feel like I'm in a rush. I take a deep breath. My chest is relieved, but the tension moves to my buttocks", " I sit cross-legged and clench my thighs. I cease to feel the floor under my feet", "I don't feel the center." The accuracy of the observations from the psychotherapist's body is surprising in the context of the drawing that Beata made on the subject of "Self-Image" (Pic. 1). It was an experience when the client first drew an image of herself (Pic. 1 - figure on the left), then moved with the image of herself in mind, and finally she drew an image of herself by moving (Pic. 1 - figure on the right). The figure on the left is depicted with black thoughts swirling and a hollow hole in the abdominal / pelvic area. Feet are suspended in the air, poorly marked. The character's hands are just as poorly marked. After the move, the image of the figure changed significantly. The character's head to the right is lit up, there is more space in the chest, and the abdomen and pelvis are filled with a peach-color shape.

One of the first experiences offered to Beata was 


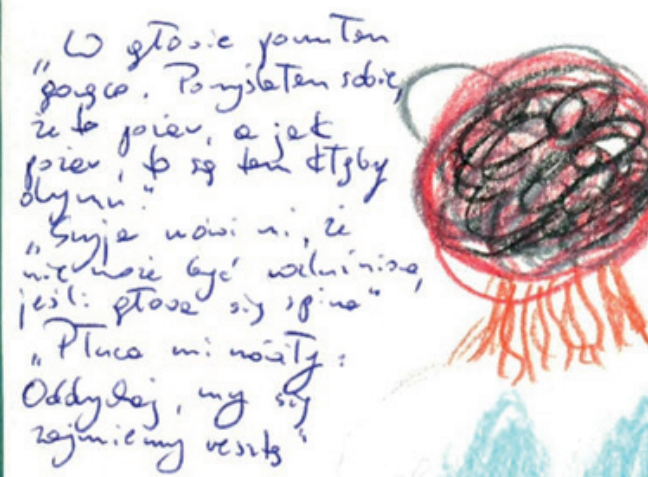<smiles>CC(C)C(C)(C)C(C)C</smiles>
tobon ugt"

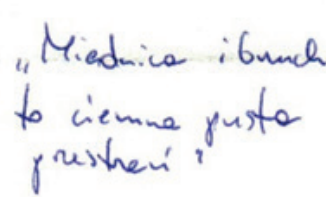

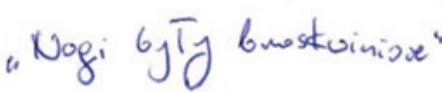

$$
\begin{aligned}
& \text { "Stopy migerem itotiotte } \\
& \text { jet pieled" }
\end{aligned}
$$

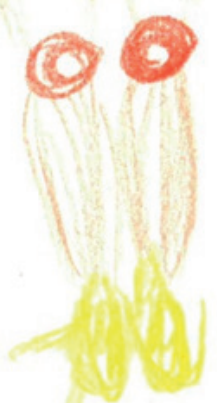

Pic. 1

a joint walk around the office. This event was very important from the diagnostic point of view and the patient's understanding. Using an active imagination, guided by a psychotherapist, the client told where she was and what she felt. When asked if she was with anyone on this walk, she replied that she was alone. At that moment, the psychotherapist experienced a sense of rejection and that he/she was unnoticed by her, despite the fact that he/ she intensely accompanied the patient in this experience. It was hypothesized that this experience was the same as what Beata feels in others relationships with many people. The patient, on the other hand, noticed that she usually makes decisions to experience her difficulties and joys on her own, thus depriving herself of the possibility of obtaining adequate help in crisis situations. Another time, the psychotherapist experienced strong emotions, similar to the desire to surround Beata with parental

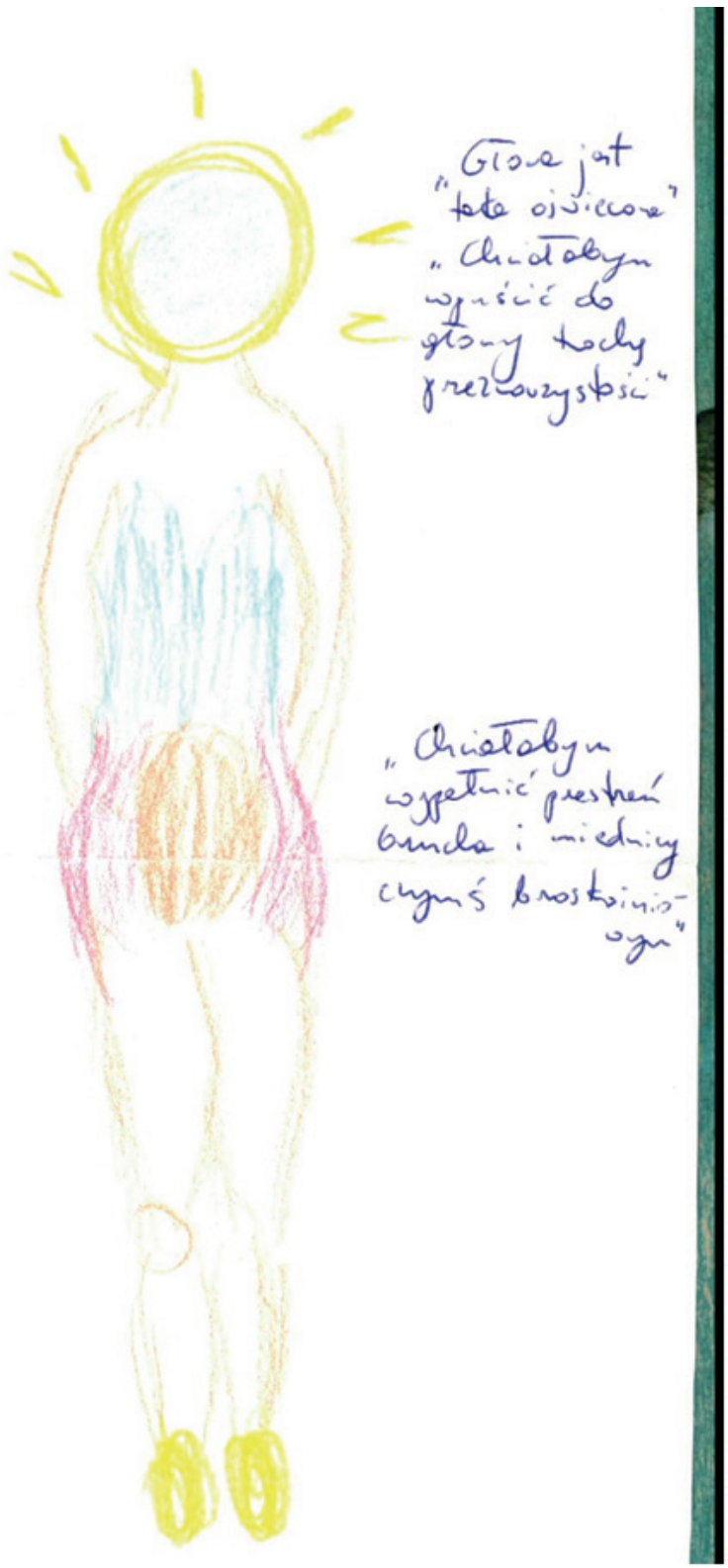

care, when she talked about difficulties with getting pregnant or when she cried after relaxing. Both the feeling of being unnoticed [48] and parental emotions [49], occurring in the psychotherapist's transference and countertransference mechanisms, have been described in the literature in the context of people diagnosed with narcissistic personality disorders.

During the initial sessions, Beata often asked to be given "homework" after the sessions. After several meetings, the patient stopped asking for experiences that she could do at home. This specific need was linked to Beata's difficulty in maintaining an image of a safe object between sessions. When the client trusted and built a lasting image of a safe facility, she no longer needed "homework" that would strengthen her confidence that her psychotherapist is a person she can come back to and refer to. 
During the sessions, the goals that the patient had set for herself at the beginning of the meetings were worked on. Beata gained access to interesting insights during the experiment while she was moving freely. In the first stage of the task, Beata danced to the music and stopped when the radio was turned off. In the second stage, she had the opportunity to decide herself when she wanted to stop and how long she would like to remain motionless. The client noticed that she felt better deciding when to stop for herself. She said that during the first part of the experience, she felt frustrated, tense in her body, "being in the middle of a step". During the second part of the task, she was calmer, her body was relaxed, she stopped at a convenient time and position. She said that she did not have to wait tense for what would happen, because she could manage her time herself. Another intervention that supported Beata in finding her limits and learning about their meaning was the interaction, when the psychotherapist approached the patient while walking, and she decided when the psychotherapist was to stop, while examining and learning about her comfort zone. The experience that when she makes a specific message, it is heard better and more often respected, was very valuable for the client.

The experience that was supposed to sensitize Beata to her needs, feelings and sensations from the body was (repeatedly repeated) moving and paying attention to movement, thoughts and what comes during the dance. During one of such sessions, the client noticed that the parts of the body that remained behind her were tense and contracted, and that what was in front of her was loose and calm. On the one hand, the patient's statement can be interpreted as her need for control, but also as experiences from the past that now have an impact on the client, and which somehow stiffen her in reacting and experiencing emotions.

Another experience that was offered to Beata was to work on her difficulty in giving up control. It consisted in the fact that the client was to relax, and the psychotherapist gently twisted her from back to stomach and from belly to back, taking care of her comfort and safety, allowing her to give up control. This experience was a strong experience for Beata, who does not often have the opportunity to trust someone. It was crucial in shaping the therapeutic relationship. During the experience, the client said that she felt vulnerable, but maybe this feeling was not bad when you are "looked after". Giving the patient a sense of security, care was taken to create a space in which her self could develop and flourish [47].

\section{Results}

The first changes that DMT psychotherapy started to bring were observed in the client's movement. Beata has become freer in her dance. Her arms and shoulders became looser, indicating a decreased sense of control in the patient. Beata more often took the shape of a torsion and a triangle, which indicated that she felt safe in the therapeutic relationship. In her dance, free flow began to appear more often, occasionally multi-directional and an alternating pattern, which testified to the better integration of the Patient in terms of internal experiences. In the verbal layer, she talked about how she breaks up conflict situations with her husband in order to give herself time to calm down and finish the conversation in a less emotional way. It became possible thanks to the client's acquisition of the ability to observe her feelings, emotions and needs. In addition, the patient found the courage to ask the company for the opportunity to work remotely and a raise. Despite the fact that the patient still experiences her difficulties with getting pregnant, she began to consider adopting a child and began to understand what the adoption process in Poland looks like. During one of the last sessions, Beata raised the issue that she was noticed at work, that she had not created a procedure for one of her tasks. This time, however, she spoke about the experience differently than usual, when someone had complaints about its functioning. She said that at first, as usual, she felt that she was not good enough to carry out the tasks assigned to her, which was associated with many unpleasant emotions, but after a while she managed to calm down. She took criticism as something that covered part of her functioning at work, did not judge herself as a bad worker and person. She spoke of this experience as situations that can happen in her job.

DMT sessions with Beata will continue for a few more meetings. At this time, it would be reasonable to work with developmental rhythms and development patterns, gaining access to early experiences and integrating them with Beata's inner life. It also seems that continuing to practice the Authentic Movement during the session will provide space for strengthening the client's sense of importance and security and caring for other therapeutic goals.

It seems that Dance Movement Psychotherapy is an effective method of working with patients with psychopathology of narcissistic personality disorders. This method makes it possible to build a sense of the patient's boundaries and needs, and to strengthen selfesteem. Sessions seem to be very helpful in integrating your inner life and the feelings you experience. In addition, it helps in coping with the internal tension of patients and gives the opportunity to expand your ranges of movement. In the verbal part, it is possible to discuss the problems that the client carries, which cause him fear, anxiety and other unpleasant emotions. 


\section{Wprowadzenie}

Taniec od wieków towarzyszy człowiekowi będąc pierwszą poznaną formą sztuki oraz jednym z głównych komponentów kultury. Stał się nieodzowną częścią życia człowieka będąc narzędziem do budowania tożsamości zbiorowej oraz językiem komunikacji pozawerbalnej. Używany w rytuałach przejścia lub integracji służył przezwyciężaniu lęku przed zmianą, śmiercią, nieznanym. Obecnie najczęściej kojarzy się z zabawą i sztuką [4].

Psychoterapia tańcem i ruchem wyłoniła się z tańca współczesnego, który wyodrębnił się jako technika w pierwszej połowie XX wieku [5]. W tym czasie taniec jako sztuka był wykorzystywany nie tylko jako forma ukazująca świat baśniowy, nierealny czy oderwany od rzeczywistości, ale również jako wyraz życia duchowego, sposób wyrażania siebie, swoich konfliktów, frustracji czy poczucia alienacji. Niedługo potem prekursorzy zaczęli wykorzystywać ruch w celach terapeutycznych [6]. Ideę psychoterapii tańcem i ruchem w Stanach Zjednoczonych zapoczątkowała Marian Chace, a w Europie Mary Whitehouse.

W XX wieku wyodrębniły się dwa nurty terapii tańcem. Jeden to taniec terapeutyczny, zwany inaczej choreoterapią, drugi to psychoterapia tańcem i ruchem (DMT, DMP). Oba nurty różni głównie rodzaj oraz znaczenie relacji terapeutycznej, z czego wynika głębokość zmiany, którą Klient może osiągnąć [6].

Psychoterapia tańcem i ruchem jest nurtem psychoterapeutycznym, który zakłada, że osoba poruszając się w sposób ekspresyjny może ukazywać swoje stany emocjonalne. Jest to metoda, gdzie ruch prowadzi do rozwoju i osobistej integracji. Psychoterapeuta stwarza warunki, w których klient może wyrazić swoje emocje w sposób bezpieczny, a uczucia spotkają się z akceptacją. DMT czerpie z wielu obszarów wiedzy, m.in. z psychologii, analizy ruchu, improwizacji, założeń tańca współczesnego, ale również sztuki i filozofii [6].

\section{Materiał i metoda}

Od listopada 2020 roku do listopada 2021 roku była prowadzona psychoterapia $\mathrm{w}$ nurcie DMT z Klientką indywidualną, Panią Beatą. Sesje psychoterapii odbywały się raz w tygodniu i trwały 55 min. Miały one charakter indywidualny. Klientka w przeszłości uczęszczała na psychoterapię prowadzoną $\mathrm{w}$ nurcie werbalnym. Imię

Tabela 1. Porównanie terapii tańcem i ruchem z choreoterapia [6]

\begin{tabular}{|c|c|c|}
\hline Obszar & Psychoterapia tańcem i ruchem & Choreoterapia \\
\hline Wykształcenie prowadzącego & $\begin{array}{c}\text { Minimum czteroletnie szkolenie } \\
\text { obejmujące szeroką wiedzę z } \\
\text { zakresu psychologii i psychoterapii }\end{array}$ & $\begin{array}{c}\text { Dwuletnie szkolenie lub seria } \\
\text { warsztatów obejmujące elementy } \\
\text { teorii psychologicznych }\end{array}$ \\
\hline Terapia własna prowadzącego & Wymagana & Zalecana \\
\hline $\begin{array}{l}\text { Superwizowanie pracy } \\
\text { terapeutycznej }\end{array}$ & Wymagane & Wymagane w trakcie szkolenia \\
\hline Główny czynnik leczący & Relacja terapeutyczna & Taniec \\
\hline Cele & $\begin{array}{l}\text { Określone przez konkretne } \\
\text { potrzeby pacjentów }\end{array}$ & $\begin{array}{l}\text { Ogólnie terapeutyczne, czasami } \\
\text { edukacyjne lub artystyczne }\end{array}$ \\
\hline Praca oparta na procesie & Tak & $\mathrm{Nie}$ \\
\hline $\begin{array}{c}\text { Choreografie proponowane przez } \\
\text { prowadzącego }\end{array}$ & $\begin{array}{l}\text { Możliwe, jeśli służą bieżącym } \\
\text { celom terapeutycznym }\end{array}$ & Tak \\
\hline Stosowanie improwizacji & Tak & Możliwe \\
\hline $\begin{array}{c}\text { Praca wewnętrzną wyobraźnią i } \\
\text { symbolizmem }\end{array}$ & Tak & Możliwa \\
\hline Wykorzystanie rytmu & Tak & Tak \\
\hline Użycie muzyki & Możliwe & Tak \\
\hline Liczba osób w grupie & Do 10 & Do 30 \\
\hline $\begin{array}{l}\text { Dotyk między terapeutą a } \\
\text { klientem }\end{array}$ & $\begin{array}{c}\text { Rzadko stosowany, w każdym } \\
\text { przypadku negocjowany wcześniej } \\
\text { z pacjentem }\end{array}$ & $\begin{array}{c}\text { Zwykle jako część typowych } \\
\text { interakcji }\end{array}$ \\
\hline Werbalne omawianie doświadczeń & Tak & Możliwe \\
\hline $\begin{array}{l}\text { Wykorzystanie obserwacji ruchu } \\
\text { w celach diagnostycznych i } \\
\text { terapeutycznych }\end{array}$ & Tak & Rzadko spotykane \\
\hline
\end{tabular}


oraz dane pacjentki zostały zmienione na potrzeby tej pracy.

Przed rozpoczęciem pracy z Panią Beatą, postawiono rozpoznanie wg klasyfikacji DSM-5 [1] oraz ICD-10 [2], którą uzupełniono diagnostyką wg Podręcznika diagnozy psychodynamicznej PDM-2 [3]. Rozpoznano u pacjentki zaburzenia osobowości typu narcystycznego.

Podczas sesji przyglądano się zjawisku przeniesienia oraz przeciwprzeniesienia, obserwowano odczucia z ciała i emocje. Interpretowano zachowania pacjentki wg teorii przywiązania Johna Bowlby'ego mówiącej o tym, że style wchodzenia $\mathrm{w}$ relację $\mathrm{z}$ innymi ludźmi kształtują się w okresie dzieciństwa poprzez relację przywiązania z rodzicami. Poczucie bezpieczeństwa $\mathrm{w}$ relacji z opiekunami, wpływa na styl radzenia sobie z występującymi w ciągu życia ciężkimi sytuacjami czy stresem. Wpływa także na intensywność ich przeżywania [7]. Wykorzystując tę teorię, dokonano bardziej świadomego dobrania strategii budowania relacji terapeutycznej. Istotna $\mathrm{w}$ budowaniu koncepcji na temat pacjenta i dobieraniu interwencji, była teoria zdolności do mentalizacji. Psycholodzy posługują się tym pojęciem od lat 70. XX wieku [8]. Proces ten jest rozumiany jako „forma przedświadomej, wyobrażeniowej aktywności umysłowej, polegająca na spostrzeganiu i interpretowaniu zachowania człowieka w kategoriach intencjonalnych stanów umysłowych (np. potrzeb, pragnień, uczuć, przekonań, celów, zamiarów, powodów)" [9]. Istotny tu jest wyobrażeniowy proces psychiczny, zdolność do tworzenia reprezentacji stanów umysłowych, różnicowanie między wewnętrzną i zewnętrzną rzeczywistością [10]. W budowaniu relacji z Panią Beatą terapeuta stosował empatyczne dostrojenie do Klientki, eksplorował odczucia, które wzbudza w nim pacjentka [11], [12] oraz stosował delikatną ekspozycję Klientki na jej emocje związane z zależnością [13], [14]. W tej kwestii ważne było podejście humanistyczne mówiące o aktywnym słuchaniu, okazywaniu troski, dzieleniu się własnymi uczuciami oraz w sytuacjach, gdy sprzyja to klientowi, dzieleniu się z nim aktualnymi doświadczeniami emocjonalnymi [15].

W praktykowaniu DMT z Panią Beatą inspirujące były słowa Janet Adler: „Kiedy jestem świadkiem twojego ruchu, nie mogę nic wiedzieć o twoim doświadczeniu. Mogę tylko znać swoje doświadczenie w twojej obecności. Zobowiązuję się śledzić swoje doznania najlepiej, jak potrafię. Moją intencją, moim zadaniem jest, aby zauważyć wszystko, co pojawia się we mnie, kiedy jestem świadkiem" [16]. Duży wpływ na budowanie relacji ruchowej z pacjentem miały superwizje. Terapeutka superwizująca proces, w swojej pracy, czerpie z metody Ruchu Autentycznego Mary Whitehouse patrząc na ruch klienta w sposób wspierającego, nieoceniającego świadka [17]. Podczas obserwacji ruchu Klienta czerpano z elementów Laban Bartenieff Movement System (LBMS) oraz Profilu Ruchowego wg Kastenberg (KMP).

\section{Wstępny wywiad}

Pani Beata ma 29 lat, jest zamężna, bezdzietna, ma wykształcenie wyższe, mieszka z mężem. Pochodzi z małej miejscowości w centralno-wschodniej Polsce. Aktualnie od 10 lat mieszka w dużym mieście. Pacjentka jest z I ciąży, I porodu, urodzona o czasie, drogami naturalnymi, w skali Apgar uzyskała 10 pkt. Nie chodziła do żłobka ani przedszkola. W pierwszych latach życia opiekowały się nią babcie: „Dzieciństwo spędziłam albo z jedną babcią albo z drugą babcią". Do zerówki poszła w wieku 6 lat, w wieku 7 lat do szkoły podstawowej. Po ukończeniu 6. klas, uczyła się w gimnazjum. W tym czasie była bardzo zaangażowana $\mathrm{w}$ życie szkoły, podejmowała ważne funkcje uczniowskie takie jak przewodnicząca klasy i szkoły, sprzedawała w szkolnym sklepiku, brała udział w olimpiadach przedmiotowych i akademiach szkolnych: „Od zerówki do końca gimnazjum byłam elitką szkolną”. Klas nie powtarzała, nie wagarowała, zachowanie miała wzorowe lub bardzo dobre, uczyła się bardzo dobrze. Następnie rozpoczęła naukę w szkole średniej. Do liceum wyjechała do większego miasta, mieszkała w bursie szkolnej. Opowiada o tym okresie w słowach: „W liceum z uczennicy piątkowej stałam się trójkową i czwórkową”, „Byłam szarą myszką, która się nie wychylała”, „W liceum nie miałam życia towarzyskiego". W wieku 19 lat rozpoczęła studia, które ukończyła po 6 latach. Od tego czasu mieszka w dużym mieście. Po studiach pracowała w korporacji. Mówi, że nie lubiła tej pracy: „Robiłam już wszystko, żeby mnie z niej wyrzucili". Od ponad roku pracuje $\mathrm{w}$ mniejszej firmie jako asystentka biura oraz zajmuje się rekrutacją nowych pracowników. Klientka określa się jako osobę wierzącą i praktykującą wiarę rzymskokatolicką.

Matka pacjentki jest $\mathrm{w}$ średnim wieku, ma wykształcenie wyższe, jest nadal aktywna zawodowo. Gdy Pani Beata miała ok. 4 lat, jej matka zaszła w kolejną ciążę, którą poroniła. 2 lata później na świat przyszedł brat pacjentki. Pacjentka ma trudną relację z matką: „Zawsze mama była tą bijącą i krzyczącą”, „Za dużo mojej mamy było w moim życiu”, „Mama zawsze mnie porównywała do innych. Klientka wspomina, że jej zdanie i zdanie jej brata nie liczyło się dla matki, która w poczuciu pacjentki, na pierwszym miejscu stawiała relacje z innymi ludźmi, a nie z dziećmi: „Zawsze mnie dziwiło, że dla innych była taka wspaniała, a dla nas potrafiła być potworem". Ojciec pacjentki ma ponad 60 lat, wykształcenie średnie, od wielu lat pracuje za granicą. Pacjentka ma dobre relacje z ojcem, choć widuje go jedynie z okazji świąt. Mówi, że zawsze lepiej jej rozmawiało się z ojcem niż matką i że łączy ich silniejsza relacja: „Całe życie wydawało mi się, że jestem 
córeczką tatusia". Pacjentka ma o 6 lat młodszego brata, który jest kierowcą: „To nie jest silny, mocny kontakt”. W ostatnim czasie brat próbuje nawiązać z pacjentką bliższe relacje, jednak ona niechętnie z nim rozmawia, jest nieufna w stosunku do niego.

Mąż Pacjentki jest w jej wieku, ma wykształcenie wyższe, pracuje w niewielkiej firmie. Z relacji pacjentki: „Traktuje pracę jako pracę, nie angażuje się w nią”. Relację partnerską z mężem, który wychowywał się w niewielkiej miejscowości, niedaleko wsi pochodzenia pacjentki, rozpoczęła $\mathrm{w}$ czasie studiów. Początkowo ich relacje układały się bardzo dobrze. Pacjentka ceniła męża za zaradność i szerokie zainteresowania. Ok. pół roku po ślubie, wg relacji pacjentki, jej mąż zmienił swoje nawyki, zaczął stosować diety, zainteresował się bioenergioterapią, zaczął pracować nad swoją relacją z Bogiem, w mniejszym stopniu bierze pod uwagę zdanie żony niż przed ślubem. W ciągu kolejnych miesięcy, pomimo rozpoczętej przez pacjentkę psychoterapii własnej, w małżeństwie narastały konflikty i kłótnie, których kulminacją była wyprowadzka męża z domu. Po kilku dniach młodzi pogodzili się, ale ta sytuacja skonfliktowała rodziny pochodzenia małżonków. Para udała się na jedno spotkanie terapii małżeńskiej, gdzie mąż otrzymał zalecenie podjęcia psychoterapii własnej. Do zalecenia się nie zastosował. Jak mówi Pani Beata: „Za to zaczął chodzić codziennie do kościoła i częściej się spowiadać". W ciągu ostatnich miesięcy został zdegradowany w pracy, zdaniem Klientki dlatego, że za mało angażował się w życie firmy. Pewne zachowania męża powodują w Klientce duży lęk, niepokój wewnętrzny oraz irytację.

Pani Beata dotychczas nie była leczona psychiatrycznie ani odwykowo. Ok. 3 mc przed rozpoczęciem psychoterapii DMT ukończyła psychoterapię w nurcie psychodynamicznym, w której udało jej się zrealizować część postawionych sobie celów. Nadal dużym problemem pozostawało odnajdywanie się $\mathrm{w}$ relacjach $\mathrm{z}$ najbliższymi. Z problemów ze zdrowiem somatycznym, pacjentka podaje zdiagnozowaną insulinooporność, $\mathrm{Z}$ powodu której stosuje dietę oraz trudności z zajściem w ciążę, z powodu których intensy wnie się diagnozuje i leczy. Klientka lubi gotować i piec, sama przygotowuje posiłki dla siebie i męża. Stosuje dietę ubogowęglowodanową oraz bezmleczną. Wypoczywa w sposób aktywny chodząc na spacery, wspinając się po górach. Trudno jest jej pozostawać w bezczynności. W ciągu weekendów, razem z mężem, jeżdżą do rodziców lub ktoś z ich znajomych lub rodziny przyjeżdża do nich.

Jako przyczyny zgłoszenia się na psychoterapię pacjentka podaje problem z agresją kierowaną do męża: „W szałach terroryzowałam męża”, „Mówiłam, że skoczę z okna”, „Raz mu prawie złamałam nos”. Pogorszenie stanu psychicznego pod postacią drażliwości, niepokoju psychoruchowego, agresji słownej i okresowo fizycznej w stosunku do męża, w znacznym stopniu występuje od ok. 2 lat, jednak klientka mówi, że od okresu nastoletniego bywała drażliwa $\mathrm{w}$ kontaktach $\mathrm{z}$ innymi ludźmi. Ostatnio pojawiły się myśli rezygnacyjne, jednak neguje występowanie myśli samobójczych. Przez ostatnie tygodnie, przed rozpoczęciem psychoterapii DMT, sytuacja w małżeństwie pacjentki uległa względnej stabilizacji. Klientka zaczęła wycofywać się z konfliktów, bardziej angażować w pracę, nie egzekwowała swoich potrzeb w domu. Z trudności, które pacjentka wymienia jako towarzyszące jej od wczesnych lat młodzieńczych, są problemy $w$ rozumieniu swoich emocji oraz werbalizowaniu swoich potrzeb. Dodatkowo Pani Beata ma silną potrzebę kontrolowania swojego życia oraz otoczenia. W wielu sytuacjach dąży do perfekcji, a jeśli jej nie osiągnie złości się na siebie: „za to, że jestem nieudolna". Ma kłopot z odpoczywaniem, podczas którego odczuwa napięcie i wyrzuty sumienia: „że jestem taka leniwa". Klientka ma trudność z cieszeniem się ze swoich sukcesów i tendencje do ukrywania ich przed bliskimi (np.: awans w pracy). Przyczynę kłopotów, z którymi się zmaga, widzi w swojej relacji z matką, która w poczuciu Pani Beaty, nie dawała jej wystarczającej bliskości, ciepła i uwagi.

\section{Wstępny wywiad}

By postawić rozpoznanie Pani Beacie, skorzystano z Klasyfikacji zaburzeń psychicznych i zaburzeń zachowania w ICD-10 [2]. Ze względu na to, że Klientce od wczesnych lat młodości towarzyszą charakterystyczne dla niej zachowania, nie wynikające bezpośrednio z choroby, uszkodzenia lub innego urazu mózgu lub innego zaburzenia psychicznego, rozpoznano u niej zaburzenie osobowości [2]. W przypadku Pani Beaty zmiany behawioralne obejmują kilka obszarów funkcjonowania i wiążą się z problemami osobistymi i zakłóceniami społecznymi [2].

Do poszerzenia diagnozy wykorzystano Kryteria Diagnostyczne Zaburzeń Psychicznych Amerykańskiego Towarzystwa Psychiatrycznego DSM-5 [1]. Ze względu na to, że Klientka wykazuje się stałym wzorcem zachowań i doświadczania emocji, który występuje od czasów nastoletnich, a który powoduje upośledzenie w funkcjonowaniu społecznym i innych ważnych obszarach życia, można u pacjentki zdiagnozować zaburzenia osobowości. Dodatkowo zachowania Pani Beaty w zakresie wyrażania emocji, funkcjonowania w relacjach międzyludzkich oraz kontroli impulsów, pozbawione są elastyczności i odbiegają od oczekiwanych w jej kręgu kulturowym. Jej zachowania nie są spowodowane działaniem substancji psychoaktywnych, ponieważ 
Klientka nie używa nikotyny, narkotyków czy dopalaczy, a alkohol pije sporadycznie. Dodatkowo nie ma przesłanek, by sądzić, że jej stan wynika z innych zaburzeń ogólnomedycznych.

Rozpoznanie typu osobowości Pani Beaty nie było oczywiste. Początkowo prezentowała się jako osoba z cechami osobowości wiązki C wg DSM-5 (unikowa, zależna, obsesyjno-kompulsyjna), ze wskazaniem na osobowość obsesyjno-kompulsyjną. Jednak po bliższym poznaniu Klientki, zauważono, że większość jej trudności związanych $\mathrm{z}$ interakcjami $\mathrm{z}$ innymi wynika z wyraźnego osłabienia poczucia własnej wartości. W jej wypowiedziach często pojawiało się przekonanie, że musi być idealna, by akceptować samą siebie i być lubiana przez innych. W kontakcie z Panią Beatą psychoterapeuta często współodczuwał jej wstyd i poczucie upokorzenia. W trakcie sesji zdarzało jej się wspominać o uczuciu zazdrości. Wtedy uwaga badaczy skierowała się ku wiązce B wg DSM-5, czyli zaburzeniom osobowości związanym $\mathrm{z}$ deficytem empatii (antyspołeczne, graniczne, histrioniczne, narcystyczne) [18]. Na zawężenie rozpoznania pozwoliły obserwacje związane z wyczuleniem Pani Beaty na punkcie własnej osoby i podatnością na „zranienie”, w konsekwencji którego Klientka zadręczała się krytyką swojej osoby oraz przeżywała upokorzenie, poniżenie, bezwartościowość i pustkę. Pani Beata spełnia kryteria narcystycznego zaburzenia osobowości wg DSM-5 w zakresie: pochłonięcia wyobrażeniami o sukcesie, doskonałości, miłości idealnej, poczuciu bycia kimś wyjątkowym, potrzebie bycia podziwianym, ograniczonej zdolności współodczuwania, poczuciu zazdrości wobec innych, okazjonalnie pojawiającym się aroganckim zachowaniem [1].

Dodatkowo do celów diagnostycznych wykonano profil funkcjonowania pacjentki wg PDM-2 [3]:

Ocena zespołów osobowości na osi P:

Pani Beata jest dość dobrze przystosowana do warunków rodzinnych, pracy i zainteresowań. Mimo to, w sytuacjach stresowych zachowuje się w sposób destruktywny dla siebie i swojego męża. Charakterystyczne dla niej jest wewnętrzne poczucie pustki i bezsensowności jej działań. Potrzebuje zewnętrznego potwierdzenia jej wartości, a jeśli jej nie otrzyma, odczuwa przygnębienie, wstyd i zazdrość. Pani Beata wykazuje cechy osobowości narcystycznej, typu „cienkoskórnego” [19], „wrażliwego” [20], [21] i „kruchego” [22].

Ocena zdolności na osi M:

- We wskaźniku zdolności do regulacji, uwagi i uczenia się [23], [24], Pani Beata zakotwicza się na poziomie 4 pkt., co oznacza, że jest skupiona, dobrze zorganizowana, potrafi wyrażać swoje myśli i emocje.
Pamięć, uwaga i funkcje wykonawcze są dobrze zintegrowane, jednak w warunkach stresu następuje ich pogorszenie i ograniczenie.

- Klientka wydaje się przeżywać i komunikować swoje stany emocjonalne w ograniczony sposób i ma trudności z doświadczaniem np. gniewu czy smutku. Często reaguje na sygnały emocjonalne innych w sposób dysfunkcjonalny, asynchroniczny, nieproporcjonalny do sytuacji, co daje jej wynik 3 we wskaźniku zdolności do przeżywania, komunikowania i rozumienia emocji [25], [26].

- Przyglądając się Pani Beacie z perspektywy jej umiejętności do wnioskowania o swoich stanach emocjonalnych i stanach umysłowych innych osób [27], oceniono ją na 3 pkt. Klientka potrafi przemyśleć i zrozumieć własne potrzeby, pragnienia i uczucia oraz wnioskować o doświadczeniach wewnętrznych innych osób. Jednak w razie konfliktu lub intensywnych emocji zauważalne jest wyraźne obniżenie zdolności do mentalizacji.

- W sferze tożsamości [28], [29] Pani Beata osiąga poziom 3. potrafiąc, $\mathrm{z}$ pewnymi ograniczeniami i $\mathrm{w}$ nadmiernym uproszczeniu, różnicować i integrować doświadczenia. U Klientki, pod wpływem silnych emocji, dochodzi do polaryzacji wewnętrznego doświadczenia.

- Zdolność do budowania relacji i intymności [30], [31] można ocenić na poziomie 3. Pani Beata jest zdolna do intymności, troski i empatii, jednak gdy zaczyna odczuwać silne emocja, takie jak lęk, gniew czy wstyd, wycofuje się z emocji, domaga się uwagi, miłości i opieki. Dość wyraźnie prezentuje się deficyt w umiejętności przyjmowania wsparcia od innych.

- Funkcjonowanie pacjentki wskazuje, że silne emocje łatwo osłabiają jej poczucie własnej wartości oraz pewność siebie, co sprawia, że jej zdolność do regulacji poczucia własnej wartości oraz wysokiej jakości doświadczenia wewnętrznego [32], [33] osiąga poziom 3.

- Pani Beata, gdy funkcjonuje w sytuacjach obciążonych afektem, ma trudności w kontrolowaniu i regulowaniu impulsów. Ma również tendencje do nadmiernej kontroli, co wskazuje, że jej zdolność do modulowania impulsów i wyrażania potrzeb [34] znajduje się na poziomie 3 .

- Zdolność do funkcjonowania obronnego [35] u Pani Beaty znajduje się na najwyższym, piątym poziomie, ponieważ przeważają u niej adaptacyjne mechanizmy obronne.

- Klientka wykazuje zaburzenia w zakresie zdolności do adaptacji, sprężystości psychicznej i wytrzymałości [36], a to sprawia, że te zdolności sytuują się na 3 poziomie.

- Pani Beata wydaje się być zmotywowana do samoobserwacji i zdolna do refleksji. Jednak pod wpływem silnego stresu jej nastawienie psychologiczne pogarsza 
się, a jej zdolność do subiektywnego doświadczenie innych i siebie zmienia się znacznie. Oznacza to, że jej zdolność do samoobserwacji [37] osiąga 3 poziom wg PDM-2.

- Zdolność do konstruowania i wykorzystywania wewnętrznych standardów i ideałów [38] Pani Beaty plasuje się na poziomie 3, ponieważ jest dość sztywna i nieelastyczna $\mathrm{w}$ tym zakresie możliwości intrapsychicznych. Dodatkowo wykazuje się chwiejnym poczuciem własnej wartości, a poczucie winy, które odczuwa, przyjmuje zadanie autokrytyka.

- Klientka przejawia pewne poczucie celu i sensu. Jednak często zdarzają się jej wątpliwości. Mówi wtedy: „To co robię nie ma sensu, nie jest ważne”. Dodatkowo Pani Beata akceptuje inne punkty widzenia w sferach, które nie są sprzeczne z jej podstawowymi ideałami. Jest to poziom 3. w skali oceny zdolności do nadawania sensu i celu [38].

Zliczając punkty, funkcjonowania na osi M wg PDM2 (tabela 1), osiągnięte przez Panią Beatę uzyskano wynik ogólny 39, co daje nam zakres M04 - Borderline [3], czyli umiarkowane upośledzenia w funkcjonowaniu psychicznym (tabela 2).

Podczas sesji dużo miejsca Pani Beata przeznacza na wątek swojej płodności. Ona i mąż starają się o dziecko od nie całych 2 lat. Pacjentka aktualnie intensywnie diagnozuje się $\mathrm{w}$ tym kierunku. Codziennie wykonuje obserwacje śluzu. Co tydzień wykonuje USG przezpochwowe, by monitorować fazę cyklu. Przyjmuje leki, które mają wspomagać pękanie pęcherzyków jajowych. Lekarzom trudno jest znaleźć uchwytną przyczynę tego, że Pani Beata nie zachodzi w ciążę. Klientce towarzyszy silny lęk, że nigdy nie będzie mogła mieć dzieci. Ten wzorzec objawów wskazuje na zaburzenia z objawami somatycznymi i pokrewne, a konkretnie zaburzenia z lękiem o stan zdrowia (S52) [39].

\section{Przebieg pierwszych sesji}

Spotkania z Klientką rozpoczęto od 3 sesji kwalifikacyjnych i diagnostycznych, podczas których można było zaobserwować, że Pani Beata to zadbana, szczupła, dość ładna, młoda kobieta. Na sesje przychodziła ubrana w sposób adekwatny. Jej ubrania zawsze były dobrane kolorystycznie, uprasowane, zadbane. Barwa jej głosu jest wysoka, dziewczęca. Podczas sesji, mówiła dużo i szybko. Główne tematy, które artykułowała, to staranie się o dziecko, konflikty z mężem i trudność w postawieniu granic przyjmując na siebie obowiązki w pracy. Często pojawiał się temat matki pacjentki, szczególnie w sytuacjach, gdy zaczynała się obwiniać za jakąś sytuację. Mówiła również dużo o bliskości i częstym poczuciu niedostatku uwagi od innych. Częste konflikty z mężem wybuchały głównie wtedy, gdy Pani Beata czuła się przez niego niezauważona, niewysłuchana lub zignorowana. W trakcie omawiania tych sytuacji, w wypowiedziach Klientki pojawiały się retrospekcje z domu rodzinnego, gdy czuła się podobnie w relacji z matką. Osoby mające skłonność do przesadnych, gwałtownych zachowań $\mathrm{w}$ relacjach $\mathrm{z}$ innymi, poczuciu niedocenienia przez ważne dla siebie osoby, poszukujące bliskości z drugim człowiekiem, jako jedyną możliwość do osiągnięcia szczęścia wykazują się lękowo-ambiwalentnym stylem przywiązania [7]. Badania nad przywiązaniem i mentalizacją u osób $\mathrm{z}$ rozpoznanym zaburzeniem osobowości typu narcystycznego i borderline wskazują na pozabezpieczne style przywiązania [40], [41], które wynikają w niesatysfakcjonujących, dezorientujących, nieprzewidywalnych relacji z bliskimi we wczesnym dzieciństwie [42], [43]. Opis Pani Beaty dotyczący jej matki potwierdzałaby tę teorię.

Tabela 2. Ocena zdolności na osi M (źródło: [3])

\begin{tabular}{|c|c|c|c|c|c|}
\hline \multicolumn{1}{|c|}{ Zdolności na osi M } & \multicolumn{3}{|c|}{ Skala oceny } \\
\hline Zdolność do regulacji, uwagi i uczenia się & 5 & 4 & 3 & 2 & 1 \\
\hline Zdolność do przeżywania, komunikowania i rozumienia emocji & 5 & 4 & 3 & 2 & 1 \\
\hline Zdolność do mentalizacji i funkcjonowania refleksyjnego & 5 & 4 & 3 & 2 & 1 \\
\hline Zdolność do różnicowania i integracji (tożsamość) & 5 & 4 & 3 & 2 & 1 \\
\hline Zdolność do budowania relacji i intymności & 5 & 4 & 3 & 2 & 1 \\
\hline Zdolność do kontroli i regulacji impulsów & 5 & 4 & 3 & 2 & 1 \\
\hline Zdolność do funkcjonowania obronnego & & & & \\
\hline Zdolność do regulacji poczucia własnej wartości oraz wysokiej jakości doświadczenia & 5 & 4 & 3 & 2 & 1 \\
\hline Zdolność do adaptacji, sprężystości psychicznej i wytrzymałości & 5 & 4 & 3 & 2 & 1 \\
\hline Zdolność do samoobserwacji (nastawienie psychologiczne) & 5 & 4 & 3 & 2 & 1 \\
\hline Zdolność do konstruowania i wykorzystywania wewnętrznych standardów i ideałów & 5 & 4 & 3 & 2 & 1 \\
\hline Zdolność do nadawania sensu & 4 & 3 & 2 & 1 \\
\hline & 5 & 4 & 3 & 2 & 1 \\
\hline Wynik ogólny \\
\hline
\end{tabular}


Tabela 3. Poziom zdolności na osi M (źródło: [3])

\begin{tabular}{|c|c|c|}
\hline Poziom/zakres & Tytuł & Opis \\
\hline \multicolumn{3}{|l|}{ Zdrowy } \\
\hline M01; 54-60 & $\begin{array}{l}\text { Zdrowe/optymalne } \\
\text { funkcjonowanie } \\
\text { psychiczne }\end{array}$ & $\begin{array}{l}\text { Optymalne lub bardzo dobre funkcjonowanie pod względem } \\
\text { wszystkich lub większości zdolności psychicznych, z } \\
\text { niewielkimi, przewidywalnymi wahaniami elastyczności i } \\
\text { adaptacji w różnych kontekstach. }\end{array}$ \\
\hline \multicolumn{3}{|l|}{ Neurotyczny } \\
\hline M02; 47-53 & $\begin{array}{l}\text { Dobre/właściwe } \\
\text { funkcjonowanie } \\
\text { psychiczne z pewnymi } \\
\text { obszarami trudności }\end{array}$ & $\begin{array}{l}\text { Właściwy poziom funkcjonowania psychicznego, z pewnymi } \\
\text { konkretnymi obszarami trudności (np.: pod względem } \\
\text { trzech lub czterech zdolności). Trudności te mogą wynikać } \\
\text { z konfliktów lub wyzwań związanych z konkretnymi } \\
\text { sytuacjami lub zdarzeniami życiowymi. }\end{array}$ \\
\hline M03; 40-46 & $\begin{array}{l}\text { Łagodne upośledzenie } \\
\text { w funkcjonowaniu } \\
\text { psychicznym }\end{array}$ & $\begin{array}{l}\text { Łagodne ograniczenia i brak elastyczności w niektórych } \\
\text { sferach funkcjonowania psychicznego, wskazujące na } \\
\text { sztywność i upośledzenie w takich obszarach, jak regulacja } \\
\text { poczucia własnej wartości, regulacja impulsów i afektów, } \\
\text { funkcjonowanie obronne oraz zdolność do samoobserwacji. }\end{array}$ \\
\hline \multicolumn{3}{|l|}{ Borderline } \\
\hline M04; 33-39 & $\begin{array}{l}\text { Umiarkowane } \\
\text { upośledzenie w } \\
\text { funkcjonowaniu } \\
\text { psychicznym }\end{array}$ & $\begin{array}{l}\text { Umiarkowane ograniczenia i brak elastyczności w } \\
\text { większości lub prawie wszystkich sferach funkcjonowania } \\
\text { psychicznego, co oddziałuje na jakość i stabilność relacji, } \\
\text { poczucie tożsamości oraz zakres tolerowanych afektów. } \\
\text { Funkcjonowanie zaczyna odzwierciedlać wyraźne } \\
\text { upośledzone adaptacje, które są opisywane jako borderline } \\
\text { w wielu pracach psychodynamicznych i które występują, z } \\
\text { rosnącym nasileniem, na następnych dwóch poziomach. }\end{array}$ \\
\hline M05; 26-32 & $\begin{array}{l}\text { Poważne upośledzenia } \\
\text { w funkcjonowaniu } \\
\text { psychicznym }\end{array}$ & $\begin{array}{l}\text { Poważne ograniczenia i zmiany w prawie wszystkich } \\
\text { sferach funkcjonowania psychicznego (np. tendencje do } \\
\text { fragmentacji i trudności w różnicowaniu Ja i obiektu), } \\
\text { wraz z ograniczeniem doświadczenia uczuć i/lub myśli w } \\
\text { najważniejszych sferach życia (tzn. miłości, pracy, zabawie). }\end{array}$ \\
\hline M06; 19-25 & $\begin{array}{l}\text { Istotne defekty w } \\
\text { zakresie podstawowych } \\
\text { funkcji psychicznych }\end{array}$ & $\begin{array}{l}\text { Istotne defekty w większości sfer funkcjonowania } \\
\text { psychicznego, wraz z problemami w organizacji i/lub } \\
\text { integracji - różnicowaniu Ja i obiektu. }\end{array}$ \\
\hline \multicolumn{3}{|l|}{ Psychotyczny } \\
\hline M07; 12-18 & $\begin{array}{c}\text { Poważne/ciężkie } \\
\text { defekty w zakresie } \\
\text { podstawowych funkcji } \\
\text { psychicznych }\end{array}$ & $\begin{array}{l}\text { Poważne i ciężkie defekty w prawie wszystkich sferach } \\
\text { funkcjonowania psychicznego, wraz z upośledzonym } \\
\text { badaniem rzeczywistości; fragmentacją i/lub trudnościami } \\
\text { w różnicowaniu Ja i obiektu; zaburzeniami percepcji, } \\
\text { integracji i regulacji afektu i myśli oraz defektami w zakresie } \\
\text { co najmniej jednej podstawowej funkcji psychicznej (np. } \\
\text { percepcji, ruchu, pamięci, regulacji, zdolności sądzenia). }\end{array}$ \\
\hline
\end{tabular}

\section{Obserwacja ruchu Klientki}

Gdy Pani Beata poruszała się podczas pierwszych sesji, dominował u niej rytm kołysania się, wzorzec rozwojowy góra-dół i prawo-lewo, ciężar lekki, przepływ zwarty, jednokierunkowość, czas wolny, przybierała kształt ściany. Nogi opierała na podłożu, dość często unosiła pięty nad ziemię. Ręce i barki miała spięte, kontrolujące, praktycznie nie poruszały się.

Rytm kołysania wg charakterystyki rytmów rozwojowych Kestenberg (Tabela 4), jest charakterystyczny dla pierwszej połowy 4 roku życia [44]. Z poziomu teraźniejszości można podejrzewać, że Pani Beata jest bardzo zaangażowana w próbę zajścia w ciążę, a ze względu na temat psychologiczny związany z opiekuńczością i rodzicielstwem, rytm ten może być dla niej bardzo bliski. Jednakże zgłębiając historię Klientki i jej rodziny zwraca uwagę fakt, że matka pacjentki poroniła dziecko, gdy Ta miała ok. 4 lata. Było to tak dużą traumą 
dla rodziny, że Klientka ma poczucie, że nie powinna rozmawiać na ten temat z matką czy ojcem, a jeszcze żyjąca babcia Pacjentki szybko kończy dyskusje związane z tamtymi przeżyciami, ponieważ nie chce poruszać tego zagadnienia. Można podejrzewać, że w tym czasie matka Pacjentki była dla niej niedostępna emocjonalnie, co wpłynęło na przeniesienie traumy z pokolenia rodziców na pokolenie Klientki. W literaturze wspomina się, że trauma przeżyta przez dziecko powoduje zatrzymanie pojawiania się kolejnych rytmów rozwojowych [44].

W ruchu Pani Beaty dominują wzorce rozwojowe góra-dół oraz prawo-lewo (Tabela 5). Wg LBMS wzorce rozwojowe dotyczą ciała, czucia, zmysłów i doznań [45]. To, że u Klientki brakuje wzorca naprzemiennego może świadczyć o braku integracji jej życia wewnętrznego oraz braku spójności w przeżywanych uczuciach. W Dynamicznych Jakościach Ruchowych Beata prezentuje ciężar lekki, czas wolny oraz jednokierunkowość, co daje action drive zwany ślizgiem (glide) [46]. Ślizg zazwyczaj jest długotrwały, lekki, bezpośredni, towarzyszy mu zwykle ograniczony przepływ, nie poddaje się przestrzeni. Interpretując poszczególne jakości ruchowe i biorąc pod uwagę, że ciężar świadczy o intencji, przepływ o poczuciu kontroli, czas o podejmowanych decyzjach, a przestrzeń o uwadze, możemy wnioskować o emocjach Klientki [46] (Tabela 6). Jej zwarty przepływ mówi nam o jej potrzebie kontroli siebie i otoczenia, co dodatkowo łączy się ze spiętymi bakami i ramionami. Psychoterapeutka, towarzysząc Pani Beacie w ruchu oraz próbując odzwierciedlić jej taniec w swoim ciele, miała poczucie kontrolowania siebie, niedopuszczania do siebie afektu. W przestrzeni Pacjentka jest jednokierunkowa, co może świadczyć o łatwości w koncentrowaniu uwagi na celu, co potwierdza wywiad zebrany z pacjentką dotyczący jej pracy oraz zorganizowania. Ciężar lekki może świadczyć o trudności w nadawaniu intencji swoim działaniom. Ta obserwacja wydaje się być spójna z nie do końca sprecyzowaną chęcią bycia w ciąży przez Panią Beatę Klientka żywi wiele ambiwalentnych emocji do posiadania dziecka. Z jednej strony bardzo chce zajść w

Tabela 4. Rytmy rozwojowe (źródło: opracowanie własne na podst. [44])

\begin{tabular}{|c|c|c|c|}
\hline wiek & faza & $\begin{array}{c}\text { Rytmy uległe (pierwsza } \\
\text { połowa roku życia) }\end{array}$ & $\begin{array}{c}\text { Rytmy waleczne (druga } \\
\text { połowa roku życia) }\end{array}$ \\
\hline 1 r.ż. & Oralna & $\begin{array}{l}\text { ssania (sucking) } \\
\text { Tematy psychologiczne: } \\
\text { potrzeba komfortu, } \\
\text { oparcia, ukojenia, } \\
\text { przywiązanie }\end{array}$ & $\begin{array}{c}\text { gryzienia (biting) } \\
\text { Tematy psychologiczne: } \\
\text { oddzielanie się, } \\
\text { formowanie granic }\end{array}$ \\
\hline 2 r.z. & Analne & $\begin{array}{l}\text { wijący (twisting) } \\
\text { Tematy psychologiczne: } \\
\text { kreatywność, gotowość } \\
\text { do zmian }\end{array}$ & $\begin{array}{l}\text { napinania (strain) } \\
\text { Tematy psychologiczne: } \\
\text { autonomia, intencje, } \\
\text { samostanowienie }\end{array}$ \\
\hline 3 r.ż. & Uretalne & $\begin{array}{l}\text { dryfowania (running) } \\
\text { Tematy psychologiczne: } \\
\text { brak celu }\end{array}$ & $\begin{array}{l}\text { start-stop (run-stop-go) } \\
\text { Tematy psychologiczne: } \\
\text { kontrola impulsów }\end{array}$ \\
\hline 4 r.ż. & Wewn.genitalne & $\begin{array}{c}\text { bujania (swaying) } \\
\text { Tematy psychologiczne: } \\
\text { opiekuńczość, } \\
\text { rodzicielstwo }\end{array}$ & $\begin{array}{c}\text { rodzenia (surging) } \\
\text { Tematy psychologiczne: }\end{array}$ \\
\hline 5 r.ż. & Zewn.genitalne & $\begin{array}{c}\text { skakania (jumping) } \\
\text { Tematy psychologiczne: } \\
\text { asertywność, budowanie } \\
\text { relacji }\end{array}$ & $\begin{array}{l}\text { tryskania (spurting) } \\
\text { Tematy psychologiczne: } \\
\text { rywalizacja }\end{array}$ \\
\hline
\end{tabular}

Tabela 5. Wzorce rozwojowe (źródło: opracowanie własne na podst. informacji z wykładów LBMS i [50])

\begin{tabular}{|c|c|}
\hline Wzorce rozwojowe: & Psychological topics: \\
\hline Oddech & O byciu \\
\hline Cor-dystal & O wychodzeniu na zewnątrz, zbieraniu informacji \\
\hline Ogon-głowa & O zabawie, przyjemności, możliwościach \\
\hline Góra-dół & O sile, mocy, sprawczości \\
\hline Prawo-lewo & O decyzji, wahaniu się \\
\hline Naprzemienny & O możliwości, integracji, spójności \\
\hline
\end{tabular}


Tabela 6. Podstawowe elementy dynamicznych jakości Wysiłku [6]

\begin{tabular}{|c|c|c|}
\hline Jakości & Skojarzenie & Wywołane doświadczenie \\
\hline $\begin{array}{c}\text { CIĘŻAR lekki/mocny } \\
\text { light weight effort/ } \\
\text { strong weight effort }\end{array}$ & Intencja & $\begin{array}{c}\text { Ciężar odnosi się do odczucia ciała samego w sobie, skóry, kości, } \\
\text { zmysłu dotyku, doświadczenia życia. Element ciężaru wiąże się z } \\
\text { wywieraniem wpływu, poczuciem istnienia. }\end{array}$ \\
\hline $\begin{array}{c}\text { PRZERSTRZEŃ } \\
\text { indirect space effort/ } \\
\text { direct space effort }\end{array}$ & Uwaga & $\begin{array}{c}\text { Przestrzeń odnosi się do uwagi skierowanej na zewnątrz, } \\
\text { perspektywy, angażuje umysłowy aspekt osobowości. Określa } \\
\text { też kierunek ruchu. Gdzie jest skierowana uwaga? Na siebie, na } \\
\text { innych, na przestrzeń, luźna, napięta. }\end{array}$ \\
\hline $\begin{array}{c}\text { TIME } \\
\text { quintained time effort/ } \\
\text { quick time effort }\end{array}$ & Decyzje & $\begin{array}{c}\text { Czas odnosi się do impulsów, decyzji, frazowania, rytmów. } \\
\text { Jest połączony z intuicją. Doświadczenie wyborów i sposobów } \\
\text { przejścia między różnymi jakościami jest związane z elementem } \\
\text { czasu. }\end{array}$ \\
\hline $\begin{array}{c}\text { FLOW } \\
\text { free flow effort/bound } \\
\text { flow effort }\end{array}$ & Rozwój & $\begin{array}{c}\text { Przepływ energii, oddechu lub siła życiowa. Zatrzymywanie lub } \\
\text { wyrażanie uczuć, doświadczenie emocji w ciele. Jak przepływ } \\
\text { energii i uczuć otwiera lub zamyka na relacje, jak nadaje } \\
\text { kierunek relacji? Przepływ to również poziom kontroli ruchu. }\end{array}$ \\
\hline
\end{tabular}

ciążę, a jej działania są silnie na tym skoncentrowane, z drugiej strony obawia się obowiązków związanych z posiadaniem dziecka oraz wynikających z tego trudności. Dodatkowo Klientka wspominała, że zdarza jej się słyszeć uwagi w pracy na temat swojej niedokładności i trudności w organizacji zadań. Pacjentka prezentuje w ruchu czas wolny, a to z kolei pokrywa się z wywiadem zebranym od Klientki, w którym potwierdza, że ma trudność z dokonywaniem szybkich decyzji, często zastanawia się nad słusznością swoich wyborów, woli najpierw możliwie najlepiej poznać temat, by dokonać decyzji. W kontekście Pani Beaty zaciekawia kształt ściany, który wskazywałby na nieufność i stawianie sztywnych granic w relacjach z innymi ludźmi, jednak kształt ten niekoniecznie powinien dziwić w obliczu trudności pacjentki, ponieważ może ukazywać chronienie się oraz nie dopuszczanie do bliskości w relacji.

Z obserwacji ruchu Pacjentki wysnuto hipotezę, że na co dzień jest osobą ambitną, dobrze zorganizowaną, próbującą kontrolować swoje otoczenie. Jednocześnie może mieć trudność z dzieleniem się odpowiedzialnością, rozpoznawaniem swoich granic oraz może mieć tendencje do przyjmowania na siebie obowiązków innych.

\section{Wyniki}

Po odbyciu wstępnych sesji zaczęto precyzować cele psychoterapii. Pani Beata jako pierwszą potrzebę podała: „Chciałabym nie MUSIEĆ tylko CHCIEĆ np. posprzątać, ugotować dla męża, bo go kocham". Zapytano ją co się wydarzy, gdy jeśli już nie będzie MUSIAŁA, okaże się, że NIE CHCE. Nie potrafiła odpowiedzieć na to pytanie, ale zgodziła się na zmodyfikowanie i zwerbalizowanie pierwszego z celu, a następnie kolejnych:

1. „Nie musieć” - nie odpowiadać na wewnętrzny przymus od razu, tylko zastanowić się nad nim.
2. „Poznanie gdzie kończą się moje potrzeby, a zaczynają potrzeby świata” - praca nad własnymi granicami.

3. „Przestać się bać, że nie dam rady” - rozpoczęcie pracy nad budową poczucia własnej wartości.

4. 4. Uczenie się odpuszczania zadań, oddawania ich, dzielenia się odpowiedzialnością.

Podczas formułowania celów psychoterapii, Pani Beata nie ujęła $w$ nich chęci pracy nad adekwatnym wyrażaniem złości. Był to aspekt, którego Klientka wolała w sobie nie dostrzegać i nie poruszać. Z punktu widzenia psychoterapii wydawało się istotne, by poruszyć ten wątek przy okazji pracy nad własnymi granicami, czy rozpoznawaniem swoich potrzeb. Widziano w tym możliwość, by Beata mogła wcześniej i bardziej świadomie wyrażać swój potencjalny dyskomfort, a nie reagować atakiem wtedy, gdy czuje, że nie ma innej możliwości, by się obronić przed przytłaczającą ją ilością obowiązków.

Dość szybko okazało się, że Klientka nie jest gotowa, by rozpocząć pracę nad czwartym celem terapeutycznym. Często mówiła, że gdyby odpuściła jakieś zadanie, to czułaby się winna. W istocie straciłaby dowód swojej wyjątkowości, a to poczucie jest bardzo potrzebne osobom z zaburzeniem osobowości typu narcystycznego, by czuć się ważnym i wartościowym. Jej trudność z oddaniem odpowiedzialności innym ujawniła się podczas doświadczenia, gdy Klientka i psychoterapeutka przeciągały się używając kawałka materiału. Gdy zaproponowano, by Pacjentka trzymając materiał oddała swój ciężar i pozwoliła sobie wychylić się poza pion, a psychoterapeutka trzymając drugi koniec utrzymałaby ją, Beata nie była wstanie tego zrobić. Dodatkowo dało to sygnał, że Klientka nie do końca ufa psychoterapeutce, nie wierzy, że mogłaby ją utrzymać, nie tylko fizycznie. Jeśli chodzi o realizację czwartego celu zauważono, że żeby stał się możliwy do 
osiągnięcia, potrzebna jest satysfakcjonująca relacja terapeutyczna. Dostępny i empatyczny psychoterapeuta mógłby dać Pacjentce poczucie bezpieczeństwa konieczne do wzrostu, zatrzymanego $\mathrm{w}$ rozwoju self [47]. W budowaniu sprzyjającej przestrzeni do tworzenia relacji terapeutycznej posłużył sposób pracy i bycia z Klientem podobny do tego, który jest charakterystyczny dla Ruchu Autentycznego. Patrząc na ruch Klienta w sposób wspierającego, nieoceniającego świadka, nazywanie tego co dzieje się w relacji i w psychoterapeutce, empatyczne dostrojenie, odzwierciedlanie pomogło w zbudowaniu zaufania między Panią Beatą a terapeutką [17].

Pracę z Klientką rozpoczęto od jej poczucia bezpieczeństwa. Posłużyło do tego, między innymi, doświadczenie z poszukiwaniem bezpiecznego miejsca w gabinecie, w którym pracowano. Klientka wolno podróżowała po całym pokoju. Długo nie mogła zdecydować się na jedno miejsce, co wiązano z jej trudnością do podejmowania decyzji. W końcu usiadła na parapecie jedynego okna w pomieszczeniu. Po chwili wstała i przeniosła na parapet wszystkie rośliny z gabinetu. Wzięła ze sobą również swoją torebkę. Gdy sama ponownie usiadła na parapecie, zaczęła patrzeć przez okno. Rozmawiając z psychoterapeutką o swoich przeżyciach nie odrywała wzroku od tego, co dzieje się za oknem. Zachowanie to wiązano z jej dużą potrzebą kontroli. Z jednej strony, pozwalając na przestawienie roślin w gabinecie, dano poczucie Beacie, że ma wpływ na zmiany, które będą miały miejsce $\mathrm{w}$ procesie, $\mathrm{z}$ drugiej strony pojawiła się obawa, czy Pacjentka nie będzie miała tendencji do prób kontrolowania sesji. Obawy potwierdziły się później. Zauważono, że części komentarzy werbalnych, które Beata otrzymywała od psychoterapeutki, zaprzeczała lub je ignorowała, by za 2 lub 3 sesje przynieść je jako swoje przemyślenia $\mathrm{z}$ ubiegłego tygodnia. To wskazywało na trudności Klientki z pozostawaniem w relacji zależności.

Budowano relację terapeutyczną w ruchu. Często korzystano z odzwierciedlania tańca Beaty. Początkowo Klientka czuła się zaskoczona, chwilami zmieszana i nie wiedziała jak się do tego odnieść. Często pytała, czy wszystko robi dobrze, czy jest wykonuje rzeczy odpowiednio. Z kolei w uczuciach psychoterapeutki pojawiała się nieadekwatność, pewien rodzaj obwiniania się o potencjalny dyskomfort pacjentki, który nie został przez nią zwerbalizowany: „Wydarzyło się coś takiego, że mam wyrzuty sumienia, że przyszłam na sesję za późno, choć dotarłam przed Panią Beatą, kilka minut przed rozpoczęciem sesji”, „Mam obawy, że jestem za bardzo konfrontująca, pomimo tego, że Pani Beata mówi, że ma miłe odczucia z sesji". Te ambiwalentne uczucia prawdopodobnie były związane z Klientką i jej niepewnością, być może frustracją w początkowej fazie budowania relacji. Z czasem, decyzja o empatycznym dostrojeniu i byciu z Pacjentką przyniosła efekt w postaci zmiany w jej ruchu i odczuciu. Beata wydawała się być swobodniejsza w swoim ruchu, mówiła o uczuciu bycia zauważoną, ważną.

Towarzysząc Beacie podczas pierwszych sesji jej psychoterapeutka, miała trudność $\mathrm{z}$ odnalezieniem swojego poczucia centrum w ciele. W notatkach zapisała: „Czuję, że żołądek podchodzi mi do gardła. Czuję jakbym się spieszyła. Biorę głęboki oddech. Czuję ulgę w klatce piersiowej, ale spięcie przenosi się do pośladków”, „Siedzę ze skrzyżowanymi nogami i zaciskam uda. Przestaję czuć podłogę pod stopami”, „Nie czuję centrum”. Trafność obserwacji z ciała psychoterapeutki zaskakuje w kontekście rysunku, który Pani Beata wykonała na temat „Obrazu siebie” (rys. 1). Było to doświadczenie, gdy Klientka najpierw rysowała obraz siebie (rys. 1 - postać po lewej), następnie poruszała się z myślą obrazu siebie, a na koniec rysowała obraz siebie po ruchu (rys. 1 - postać po prawej). Postać po lewej stronie jest przedstawiona z kłębiącymi się czarnymi myślami oraz pustą dziurą w okolicy brzucha/miednicy. Stopy są zawieszone w powietrzu, słabo zaznaczone. Równie słabo są zaznaczone ręce postaci. Po ruchu obraz postaci znacznie się zmienił. Głowa postaci po prawej jest rozświetlona, w klatce piersiowej jest więcej przestrzeni, a brzuch i miednica są wypełnione brzoskwiniowym kształtem.

Jednym z pierwszych doświadczeń, które zaproponowano Beacie był wspólny spacer po gabinecie. Wydarzenie to było bardzo ważne z punktu widzenia diagnostycznego oraz zrozumienia Pacjentki. Używając aktywnej wyobraźni, naprowadzana przez psychoterapeutkę, Klientka opowiadał gdzie się znajduje i co czuje. Gdy zapytano ją, czy jest z kimś na tym spacerze, odpowiedziała, że jest sama. W tamtym momencie psychoterapeutka doświadczyła poczucia odrzucenia oraz tego, że jestem przez nią niezauważana, pomimo tego, że intensywnie towarzyszyłam pacjentce $\mathrm{w}$ tym doświadczeniu. Wysunięto hipotezę, że przeżycie to było tożsame z tym, co Beata odczuwa w licznych relacjach z wieloma osobami. Pacjentka natomiast zauważyła, że zazwyczaj podejmuje decyzje, by samodzielnie przeżywać swoje trudności oraz radości, tym samym odbierając sobie możliwość uzyskania adekwatnej pomocy w kryzysowych sytuacjach. Innym razem zdarzyło się psychoterapeutce żywić silne emocje, podobne do chęci otoczenia Beaty opieką rodzicielską, gdy opowiadała o trudnościach z zajściem w ciążę lub gdy rozpłakała się po relaksacji. Zarówno odczucie niezauważenia [48] jak i emocje rodzicielskie [49], występujące u psychoterapeuty $\mathrm{w}$ mechanizmie przeniesienia i przeciwprzeniesienia, były opisywane w literaturze w kontekście osób z rozpoznaniem zaburzeń osobowości typu narcystycznego. 

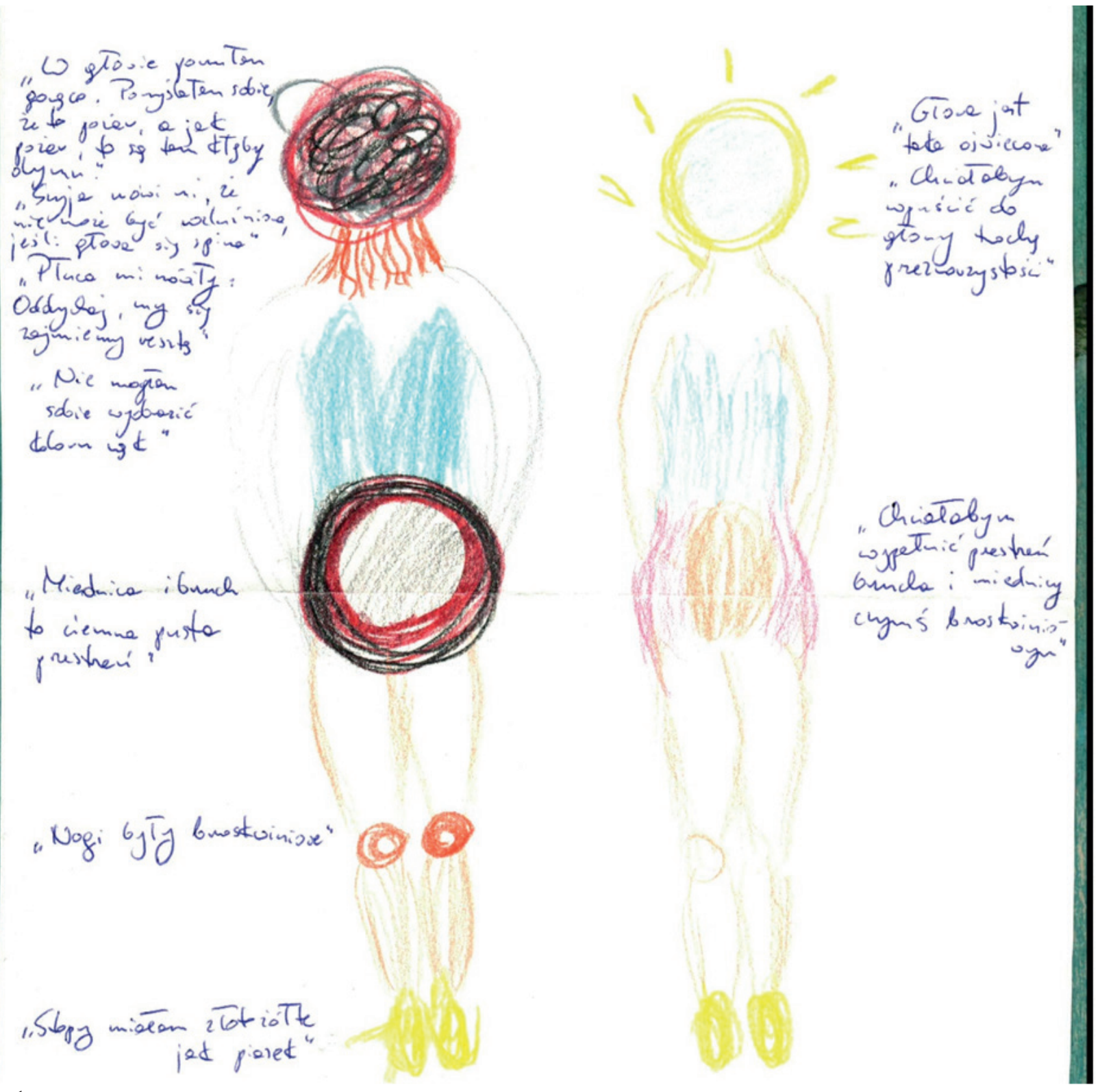

Rys. 1

Podczas początkowych sesji Pani Beata często prosiła o dawania jej „zadań domowych” po sesjach. Po kilku spotkaniach Pacjentka przestała prosić o dawanie jej doświadczeń, które mogłaby wykonywać w domu. Tę specyficzną potrzebę powiązano z trudnością Pani Beaty do utrzymania obrazu bezpiecznego obiektu pomiędzy sesjami. Gdy Klientka zaufała i zbudowała trwały obraz bezpiecznego obiektu, przestała potrzebować „zadań domowych", które utrwalałyby ją w pewności, że jej psychoterapeutka jest osobą, do której może wrócić i się odwołać.

W trakcie sesji pracowano nad celami, które pacjentka postawiła sobie na początku spotkań. Beata uzyskała dostęp do ciekawych spostrzeżeń podczas doświadczenia gdy poruszała się swobodnie. W pierwszym etapie zadania Beata tańczyła do muzyki i zatrzymywała się gdy wyciszano radio. W drugim etapie miała możliwość sama zadecydować kiedy chce się zatrzymać i jak długo chce pozostać w bezruchu. Klientka zauważyła, że czuje się lepiej, gdy sama decyduje o tym, kiedy się zatrzymać. Mówiła, że podczas pierwszej części doświadczenia odczuwała frustrację, napięcie w ciele, „bycie w pół kroku”. Podczas drugiej części zadania była spokojniejsza, jej ciało było rozluźnione, zatrzymywała się w dogodnym dla niej czasie i pozycji. Mówiła, że nie musi z napięciem czekać na to, co się stanie, bo może zarządzać swoim czasem sama. Inną interwencją, która wsparła Beatę w odnajdywaniu swoich granic i poznawaniu ich znaczenia była interakcja, kiedy psychoterapeutka idąc zbliżała się do Pacjentki, a ta decydowała kiedy psychoterapeutka ma się zatrzymać, jednocześnie badając i poznając swoją strefę komfortu. Doświadczenie tego, że gdy pada z jej strony konkretny komunikat, to jest on lepiej słyszany i częściej respektowany, był dla Klientki 
bardzo wartościowy.

Doświadczenie, które miało uwrażliwić Beatę na swoje potrzeby, uczucia i odczucia z ciała było (wielokrotnie powtarzane) poruszanie się i zwracanie uwagi na ruch, myśli i to co przychodzi podczas tańca. Podczas jednej z takich sesji Klientka zauważyła, że części ciała, które pozostają za nią, są spięte i przykurczone, a to co znajduje się przed nią jest luźne i spokojne. Z jednej strony wypowiedź Pacjentki można interpretować jako jej potrzebę kontroli, ale również jako doświadczenia z przeszłości, które teraz mają wpływ na Klientkę, a które w jakiś sposób usztywnia ją w reagowaniu i doświadczaniu emocji.

Kolejne doświadczenie, które zaproponowano Beacie miało na celu pracę nad jej trudnością z oddawaniem kontroli. Polegało na tym, że Klientka miała się rozluźnić, a psychoterapeutka delikatnie przekręcałam ją z pleców na brzuch i z brzucha na plecy, dbając o jej komfort i bezpieczeństwo, pozwalając na oddanie kontroli. Doświadczenie to było mocnym przeżyciem dla Pani Beaty, która nie często ma okazję, by komuś zaufać. Było ono kluczowe w kształtowaniu się relacji terapeutycznej. W trakcie doświadczenia Klientka mówiła, że czuje się bezbronna, ale może to poczucie nie jest niczym złym, gdy jest się „zaopiekowanym”. Dając pacjentce poczucie bezpieczeństwa, zadbano o przestrzeń, w której jej self mogłoby się rozwijać i rozkwitać [47].

\section{Podsumowanie}

Pierwsze zmiany, które zaczęła przynosić psychoterapia DMT zaobserwowano w ruchu Klientki. Beata stała się swobodniejsza w swoim tańcu. Jej ramiona i barki stały się luźniejsze, co wskazywał na zmniejszenie poczucia kontroli u pacjentki. Beata częściej przybierała kształt skrętny oraz trójkąta, co wskazywało, że czuje się bezpiecznie w relacji terapeutycznej. W jej tańcu częściej zaczął pojawiać się przepływ swobodny, okazjonalnie wielokierunkowość oraz wzorzec naprzemienny, który świadczył o lepszej integracji Pacjentki w zakresie przeżyć wewnętrznych. W warstwie werbalnej opowiadała o tym, jak przerywa konfliktowe sytuacje z mężem, by dać sobie czas na wyciszenie się i dokończenie rozmowy w mniej emocjonalny sposób. Stało się to możliwe, dzięki nabyciu przez Klientkę umiejętności przyglądania się swoim odczuciom, emocjom i potrzebom. Ponadto pacjentka zdobyła się na odwagę, by poprosić w firmie o możliwość pracy zdalnej w oraz podwyżkę. Pomimo tego, że pacjentka nadal bardzo przeżywa swoje trudności z zajściem w ciążę, zaczęła brać pod uwagę adopcję dziecka oraz zaczęła się orientować, jak wygląda proces adopcyjny w Polsce. Podczas jednej z ostatnich sesji Beata wniosła zagadnienie, że została jej zwrócona uwaga w pracy, że nie stworzyła procedury do jednego ze swoich zadań. Tym razem jednak inaczej opowiadała o tym doświadczeniu niż zazwyczaj, gdy ktoś miał zażalenia do jej funkcjonowania. Mówiła, że początkowo, tak jak zazwyczaj poczuła, że nie jest wystarczająco dobra, by wykonywać powierzone jej zadania, z czym wiązało się wiele nieprzyjemnych emocji, ale po chwili zdołała się uspokoić. Przyjęła krytykę jako coś, co obejmowało część jej funkcjonowania w pracy, nie oceniała siebie jako złego pracownika i osobę. Mówiła o tym doświadczeniu jako o sytuacjach, które mogą zdarzać się w życiu zawodowym.

Sesje DMT z Panią Beatą będą trwały jeszcze przez kilka spotkań. W tym czasie zasadna mogłaby być praca z rytmami rozwojowymi oraz wzorcami rozwojowymi uzyskując dostęp do wczesnych przeżyć i integrując je z życiem wewnętrznym Beaty. Wydaje się również, że dalsze praktykowanie Ruchu Autentycznego podczas sesji da przestrzeń na wzmacnianie poczucia ważności i bezpieczeństwa Klientki i zajęcie się w sposób opiekuńczy pozostałymi celami terapeutycznymi.

Wydaje się, że Psychoterapia Tańcem i Ruchem jest skuteczną metodą pracy z pacjentami z psychopatologią zaburzeń osobowości typu narcystycznego. Metoda ta daje możliwość budowania poczucia granic i potrzeb pacjenta oraz wzmacnianie poczucia własnej wartości. Sesje wydają się być bardzo pomocne w integrowaniu życia wewnętrznego oraz przeżywanych uczuć. Dodatkowo pomaga $\mathrm{w}$ radzeniu sobie $\mathrm{z}$ napięciem wewnętrznym Pacjentów oraz daje możliwość poszerzenia swoich zakresów ruchowych. W części werbalnej możliwe jest omówienie problemów, które nosi w sobie Klient, a które powodują $\mathrm{w}$ nim lęk, niepokój i inne nieprzyjemne $\mathrm{w}$ odczuciu emocje.

\section{Conflict of interest}

The author has declared no conflict of interest.

\section{References:}

1. Gałecki P., (i wsp.), (red. wyd. pol.). Kryteria Diagnostyczne Zaburzeń Psychicznych American Psychiatric Association. Wrocław: Edra Urban \& Partner. 2018.

2. Jaroszyński J., Brykczyńska C., Habrat B., Namysłowska I., Parnowski T., Pużyński S., Siwiak-Kobayashi M., Szelenberger W., Wciórka J., (red. wyd. pol.). Klasyfikacja zaburzeń psychicznych i zaburzeń zachowania w ICD-10 - Opisy kliniczne i wskazówki diagnostyczne. Kraków-Warszawa: Uniwersyteckie Wydawnictwo Medyczne „Vesallius”, Instytut Psychiatrii i Neurologii. 2007.

3. Lingiardi A., McWilliams N. PDM-2 Podręcznik diagnozy psychodynamicznej. Kraków: Wydawnictwo Uniwesytetu Jagiellońskiego. 2019; 45-377.

4. Sachs C. World history of the dance. New York: W.W. Norton \& Co. 1965.

5. Sorell W. Dance in its time. New York: Columbia University Press. 1986.

6. Pędzich Z., (i inn.). Psychoterapia tańcem i ruchem - Teoria i praktyka. Sopot: GWP. 2018; 13-48. 
7. Bowlby J. Przywiązanie. „Biblioteka Klasyków Psychologii”, Wydawnictwo Naukowe PWN. 2021.

8. Brown D.G. Drowsiness in the countertransference. International Review of Psycho-Analysis. 1977; 4(4):481-492.

9. Allen J.G., Fonagy P., Bateman A. Mentalizing in Clinical Practice. Washington: American Psychiatric Publishing Inc. 2008.

10. Marszał M. Mentalizacja w kontekście przywiązania. Warszawa: Difin. 2015.

11. Kohut H. The analysis of the self: A systematic approach to the psychoanalytic treatment of narcissistic personality disorders. New York: International Universities Press. 1971.

12. Kohut, H. The restoration of the self. New York: International Universities Press. 1977.

13. Kernberg O.F. Borderline conditions and pathological narcissism. New York \& London: Aronson. 1975.

14. Kernberg O.F. Severe personality disorders: Psychotherapeutic strategies. New Haven, CT: Yale University Press. 1984.

15. Rogers C.R. Terapia nastawiona na klienta grupy spotkaniowe. Thesauruss Press. 1991.

16. Adler J. Offering from the conscious body: The discipline of authentic movement. Rochester: Inner Traditions. 2002;10.

17. Pędzich Z., (i inn.) Psychoterapia tańcem i ruchem - Terapia indywidualna i grupowa. Sopot: GWP. 2014;205-229.

18. Baron-Cohen S. Teoria zła o empatii i genezie okrucieństwa. Wyd. Smak Słowa. 2015.

19. Rosenfeld H. Impasse and interpretation. London: Routledge. 1987.

20. Pincus A.L., Cain N.M., Wright A.G.C. Narcissistic grandiosity and narcissistic vulnerability in psychotherapy. Personality Disorders: Theory, Research, and Treatment. 2014; 5:439-443.

21. Pincus A.L., Roche M.J., Narcissistic grandiosity and narcissistic vulnerability, [w:] Campbell, W.K., Miller J.D. (red.), Handbook of narcissism and narcissistic personality disorder. Hoboken, $\mathrm{NJ}$ : Wiley. 2011; 31-40.

22. Russ E., Shedler J., Bradley R., Westen D. Refining the construct of narcissistic personality disorder: Diagnostic criteria and subtypes. American Journal of Psychiatry. 2008; 165:1473-1481.

23. Conway F., (red). Attention deficit hyperactivity disorder: Integration of cognitive, neuropsychological, and psychodynamic perspectives in psychotherapy. New York: Routlegde. 2014.

24. Hobson P. The cradle of thought: Exploring the origins of thinking. New York: Oxford University Press. 2004.

25. Bates G.C. Affect regulation. "International Jurnal of Psychoanalysis".2000; 81:317-319.

26. Lane R.D., Schwartz G.E. Levels of emotional awareness: A cognitive-developmental theory and its application to psychopathology. American Journal of Psychiatry. 1987; 144:133-143.

27. Muller C., Kaufhold J., Overbeck G., Grabhorn R. The importance of reflective functioning to the diagnosis of psychic structure. Psychology and Psychotherapy: Theory, Research and Practice. 2006; 79:485-494.

28. Ericson E.H. The problem of ego identity. Journal of the American Psychoanalytic Association. 1956; 4:56-121.

29. Wilkinson-Ryan T., Westen D. Identity disturbance in borderline personality disorder: An empirical investigation. American Journal of Psychiatry. 2000; 157:528-541.

30. Kernberg O.F. The inseparable nature of love and aggression: Clinical and theoretical perspectives. Washington, DC: American Psychiatric Publishing. 2012.

31. Yoo H., Bartle-Haring S., Day R.H., Gangamma R. Couple communication, emotional and sexual intimacy, and relationship satisfaction. Journal of Sex and Marital Therapy. 2014; 40:275-
293.

32. Horowitz L.M. Interpersonal fundations of psychopathology. Washington, DC: American Psychological Association. 2004.

33. Silverstein M.L. Disorders of the self: A personality-guided approach. Washington, DC: American Psychological Association. 2007.

34. Schore A.N. Affect dysregulation and disorder of the self. New York: Norton. 2003.

35. Vaillant G.E. The wisdom of the ego. Cambridge, MA: Harvard University Press. 1993.

36. Bornstein R.F., Languirand M.A. Healthy dependency. New York: Newmarket Press. 2003

37. Appelbaum S.A. Psychological-mindedness: Word, concept and essence. "International Journal of Psycho-Analysis". 1973; 54:35-46.

38. Peterson C., Seligman M.E.P. Character strengths and virtues. Washington, DC: American Psychological Association. 2004.

39. Fenichel 0. The psychoanalytic theory of neurosis. New York: Norton. 1945.

40. Diamond D., (i wsp.). Attachment and mentalization in female patients with comorbid narcissistic and borderline personality disorder. Personality Disorders. 2014; 5:428-433.

41. Diamond D., (i wsp.). Transference focused psychotherapy for patients with comorbid narcissistic and borderline personality disorder. Psychoanalytic Inquiry. 2013; 33:527-551.

42. Fossati A., (i wsp.). The structure of pathological narcissism and its relationships with adults attachment styles: A study of Italian nonclinical and clinical adult participants. Psychoanalytic Psychology. 2015; 32:403-431.

43. Kealy D., Ogrodniczuk J.S., Joyce A.S., Steinberg P.I., Piper W.E. Narcissism and relational representations among psychiatric outpatients. Journal of Personality Disorder. 2013; 27:1-5.

44. Kestenberg J., Loman S., Sossin M. The meaning of movement. New York: Routledge. 2018.

45. Chaiklin S., Wengrower H. The art and science of Dance/ Movement Therapy. Routledge. 2009.

46. Newlove J., Dalby J. Laban dla wszystkich. Warszawa: Kined. 2011.

47. Gabbard G.O. Psychiatria psychodynamiczna w praktyce klinicznej. Kraków: Wydawnictwo Uniwersytetu Jagiellońskiego. 2014.

48. Colli A., Tanzilli A., Diaggio G., Lingiardi V. Patient personalityand therapist response: An empirical investigation. American Journal of Psychiatry. 2014; 171:102-108.

49. Gazzillo F., Lingiardi V., Del Corno F., McWiliams N., (i wsp.). Clinicians' emotional responses and Psychodynamic Diagnostic Manual adult personality disorders: A clinically relevant empirical investigation. Psychotherapy. 2015; 52(2):238-246.

50. Meekums B. Dance movement therapy: A creative psychotherapeutic approach. London: Sage Publications. 2002.

\section{Corresponding author}

Ewelina Drzał

I Department of Psychiatry, Psychotherapy and Early Intervention, Medical Univercity of Lublin

Ul. Głuska 1, 20-439 Lublin

ewelina.drzal@gmail.com

Otrzymano: 12.11.2021

Zrecenzowano: 17.11.2021

Przyjęto do druku: 28.12.2021 